4h. 2652

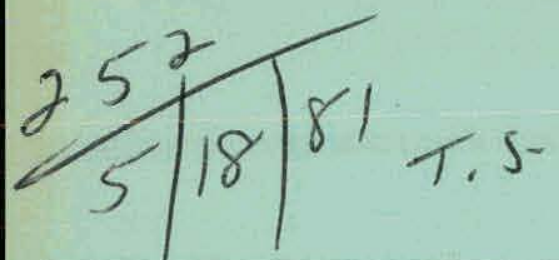

Assistant Secretary for Conservation and Renewable Energy

Division of Hydroelectric Resources Development

Washington, D.C. 20461

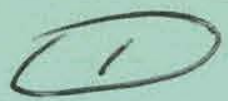

\title{
MASTER
}

\section{A Manual for Development of Small Scale Hydroelectric Projects by Public Entities}

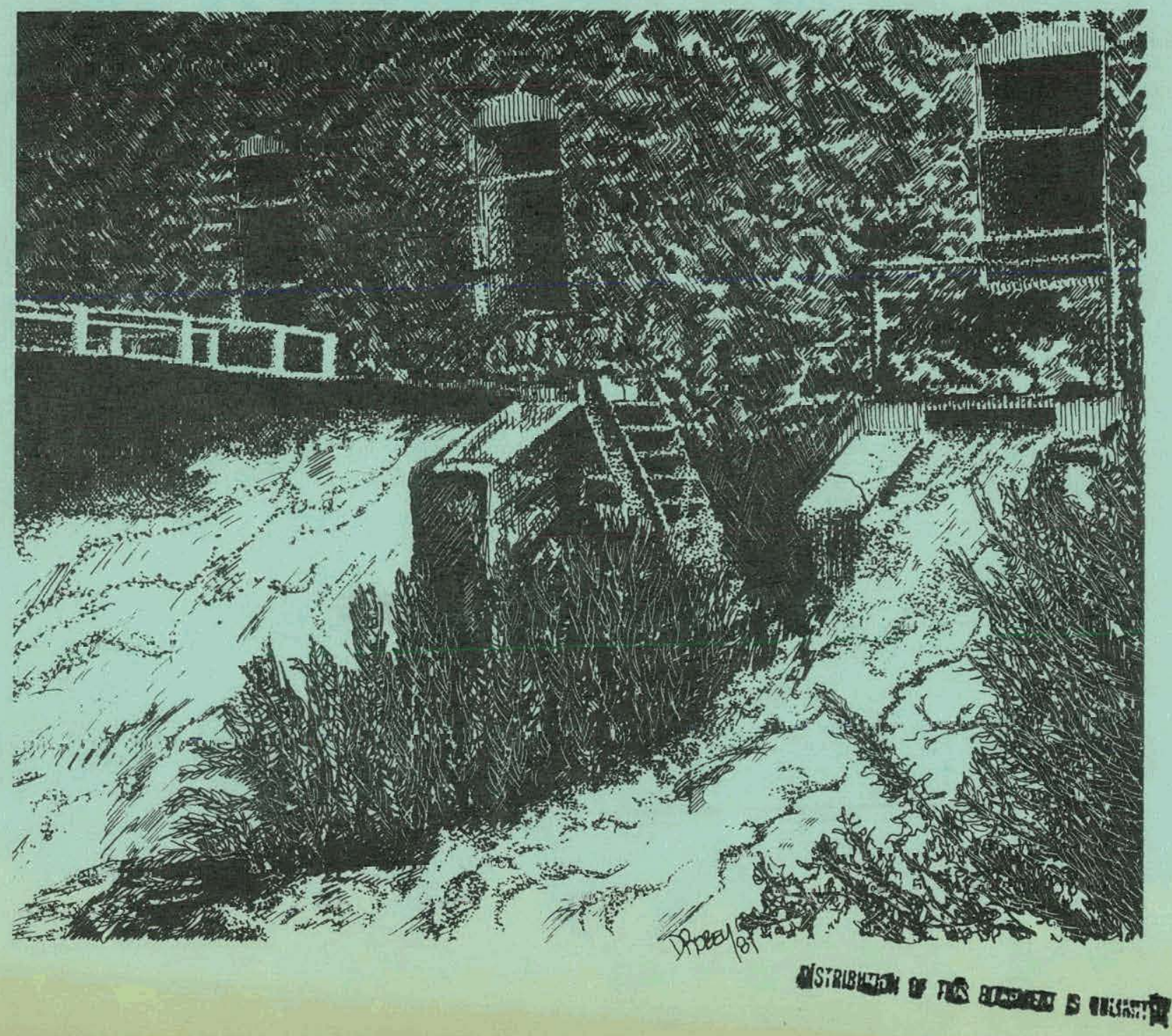




\section{DISCLAIMER}

This report was prepared as an account of work sponsored by an agency of the United States Government. Neither the United States Government nor any agency Thereof, nor any of their employees, makes any warranty, express or implied, or assumes any legal liability or responsibility for the accuracy, completeness, or usefulness of any information, apparatus, product, or process disclosed, or represents that its use would not infringe privately owned rights. Reference herein to any specific commercial product, process, or service by trade name, trademark, manufacturer, or otherwise does not necessarily constitute or imply its endorsement, recommendation, or favoring by the United States Government or any agency thereof. The views and opinions of authors expressed herein do not necessarily state or reflect those of the United States Government or any agency thereof. 


\section{DISCLAIMER}

Portions of this document may be illegible in electronic image products. Images are produced from the best available original document. 


\section{NOTICE}

This report was prepared as an account of work sponsored by the United States Government. Neither the United States nor the United States Department of Energy, nor any of their employees, makes any warranty, express or implied, or assumes any legal liability or re sponsibility for the accuracy, completeness, or usefulness of any information, apparatus, product, or process disclosed, or represents that its use would not infringe privately owned rights. Reference herein to any specific commercial product, process, or service by trade name, mark, manufacturer, or otherwise, does not necessarily constitute or imply its endorsement, recommendation, or favoring by the United States Government or any agency thereof. The views and opinions of authors expressed herein do not necessarily state or re. flect those of the United States Government or any agency thereof.

Ava1lable from:

National Iechnical Information Service (NIIS)

D.S. Department of Commerce

5285 Port Royal Road

Springfield, Virginia 22161

Price: Printed copy: $\$ 6.50$

$$
\text { Microfiche: } \$ 3.50
$$

For sale by the Superintendent of Documents, U.S. Goverument Printing Office. Washington, D.C. 20402 
Assistant Secretary for Conservation and Renewable Energy

Division of Hydroelectric Resources

Development

Washington, D.C. 20461

\section{A Manual for Development of Small Scale Hydroelectric Projects by Public Entities}

Prepared by:

The Energy Law Institute

Franklin Pierce Law Institute Center

Concord, New Hampshire 03301

Under Contract No. AS02-78RA04934

March 1981

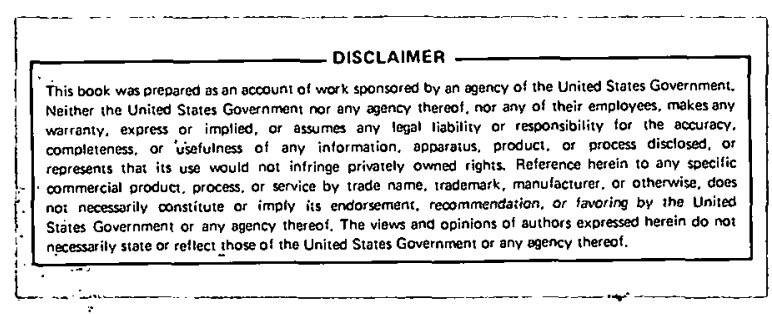


PREFACE

This document was prepared by the Energy Law Institute (ELI) pursuant to United States Department of Energy (DOE) Contract No. DE-AS02-78RA04934.A003. The opinions, findings, conclusions and recommendations expressed herein are exclusively those of the authors and do not necessarily reflect the views of DOE. Neither DOE, nor ELI, nor any person acting on behalf of either:

a. Makes any warranty or representation, express or implied, with respect to the accuracy, completeness or usefulness of the information contained in this document; or

b. Assumes any liabilities with respect to the use of, or for injury resulting from the use of, any information disclosed in this document.

The Energy Law Institute and its staff wish to extend their sincere thanks to the many persons who assisted in the preparation of this document. Unfortunately, the number of persons who contributed is so great that it is impossible to thank each one by name. However, the members of the staff would like to particularly acknowledge the contributions of Hardy Eubanks of Blyth, Eastman, Paine, and Webber; Frank Frisk of Fairman, Frisk and Monoco; Peter Freund of Goldman Sachs; Albert H. Garner of Lazard Freres; Lee Goodwin of Patton, Boggs and Blow; and David Willer of Tudor Engineering.

Principal Investigator: Professor Peter W. Brown

Fellow in Economics: John A. Fox, Ph.D.

Senior Research Fellow: William H. Wilson, Jr., Esq.

Research Assistants: Michael B. King

Thomas B. Getz

Energy Law Institute

March 27, 1981 
Preface $\ldots \ldots \ldots \ldots \ldots \ldots \ldots \ldots \ldots \ldots \ldots \ldots \ldots \ldots \ldots \ldots \ldots \ldots \ldots \ldots \ldots$

I. Introduction $\ldots \ldots \ldots \ldots \ldots \ldots \ldots \ldots \ldots \ldots \ldots \ldots \ldots \ldots \ldots$

A. Purpose of the Manual........................ 1

B. Recent Developments Favoring sSH................. 1

C. How Best to Use the Manual........................

II. The Hydroelectric Development Process............... 3

A. Introduction............................

B. Reconnaissance study......................... 3

C. Feasibility study............................ 4

D. Permits, Licensing, and Exemptions............... 4

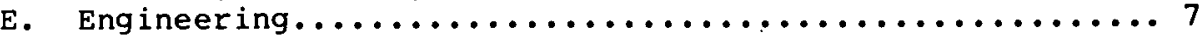

F. Power Contract Negotiations.....................

G. Construction..............................

III. General Organizational and Business Considerations.........10

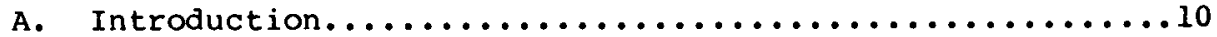

B. Authorization to Proceed with a SSH Project...........10

C. Public Ownership and Development...................

D. Joint Private and Public Ownership or Development......11

E. Disposition of the Site - the Political Subdivision as a Passive Participant.....................12

F. Caveats for FERC Licenses and Exemptions............13

G. How to Evaluate Alternative Proposals for Development...14

IV. Financing and Sources of Funds....................

A. Introduction................................

B. Financing Initial project costs..................

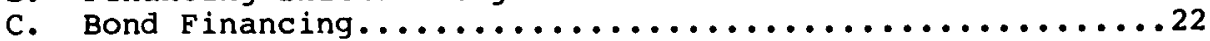

1. Introduction..........................22

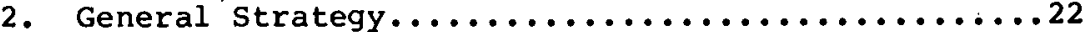

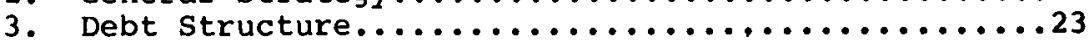

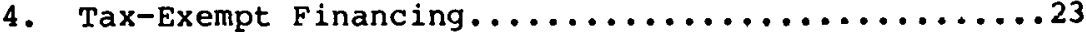

5. Federal Incume Tax Requirements:

Section $103(b)$ of the Internal Revenue Code......24

D. Federal Financial Assistance..................... 32

Document Fontnooter.................................. 


\section{Introduction}

\section{A. Purpose of the Manual}

This manual is designed to provide guidance to towns, cities, counties and other political subdivisions which are interested in undertaking or participating in small scale hydroelectric (SSH) development within or close to their territorial boundaries. The manual is primarily directed to those political subdivisions which either own or have access to. a site, are interested in exploring the prospects for development of the site and do not have longstanding experience in the electric power development.

For purposes of this manual a small scale hydroelectric project is a project of 25 to 30 MWs or less and utilizes an existing dam or structure or utilizes the site characteristics of partially breached dams or structures. As the reader will observe from the discussion that follows, several incentives under federal and state law have been implemented which favor small scale hydroelectric development at existing sites. This manual is designed to assist political subdivisions in taking advantage of these incentives and devising strategies for development. The manual will provide information to political subdivisions as to what to expect in the development process and the kinds of informed questions to ask of paid advisers. The manual, however, cannot be and should not be used as a substitute for competent advice and assistance from experienced lawyers, engineers, accountants and financing experts.

\section{B. Recent Developments Favoring SSH}

There has been a great increase in interest in the development of small scale hydroelectric facilities. A number of factors including rapidly increasing energy prices, increasing interest in renewable energy sources, and environmental considerations have made SSH facilities attractive.

However, until 1978 a number of legal and other obstacles hindered the development of SSH projects. For example, before 1978 SSH facilities were subject to many of the same regulatory and licensing procedures as large new hydropower facilities. Furthermore, an SSH facility could experience great difficulty marketing its electricity at a reasonable price because existing utilities (the only buyers) were not required to purchase the power nor were there any standards for setting the price.

Since 1978 new federal legislation has removed some of the obstacles to sSH projects and has created substantial incentives for SSH development. The Public Utility Regulatory Policies Act (PURPA) of 1978 provides several incentives for SSH development. PURPA reguires electric utilities to purchase electric energy and capacity from ssh facilities and other qualifying facilities at the utilities' marginal or avoided cost. PURPA requires the utilities to provide information concerning these coste both at present and in the future. PURPA exempts most small power production facilities from certain provisions of the Federal Power Act, from all provisions of the Public Utility Holding Company Act regarding electric utilities, and from state laws regulating the financial organization and rates of electric utilities. PURPA also provides a loan program for feasibility studies and construction and an expedited licensing process.

The Crude oil windfall profit Tax Act of 1980 provides tax incentives for the development of SSH projects at existing dam sites or at sites which do not use a dam or impoundment. Energy tax credits of 11 percent (in addition to the regular 10 percent credit) are available on projects up to 25 megawatts and a declining credit is available on projects up to 125 megawatts. Also projects on certain publicly owned dams can be fully or partially financed by tax exempt industrial development bonds.

The Federal Energy Security Act of 1980 allows the Federal Energy Regulatory Commission (FERC) at its discretion to wholly or partially exempt from licensing SSH projects of less than 5 megawatts. In addition the FERC licensing procedure has been streamlined to facilitate licensing of other SSH projects.

\section{How Best to Use the Manual}

This manual cannot and should not he used as a substitute fur coinpetent legal, enyiluerlng, accounting and financial advice and services. It can be used by town managers and other officials to comprehend the SSH development processes so that these 
officials know what to expect and are able to ask informed questions. Because the manual deals with the knowledge and experience of various disciplines (law, enyineeriny and finance) it should also be helpful to engineering firms, accountants and others who have been retained by a political subdivision to perform services in conjunction with SSH development.

This manual should also be read in conjunction with another document published by the Energy Law Institute entitled, "Financing Private, Small Scale Hydroelectric Projects" ("Financing Private SSH"). This document describes in depth various aspects of SSH development which also pertain to SSH development by political subdivisions. Where appropriate, references will be made to the document on private financing.

Finally, the manual may assist political subdivisions in making choices from among a variety of development strategies. The manual will display methods which may be used by political subdivisions to assist them in making the choice. Essentially political subdivisions will be confronted with the choice of proceeding with development and, if that choice is made, then choosing again which arrangement for development is best suited for the subdivision involved. Is it better for a town to sell its site at public auction to the highest bidder? Should the town participate in the development with a private entrepreneur, or the local investor owned utility? While this manual will not answer these questions definitively (each site and political subdivision will have its own needs), the methods discussed here are designed to assist in finding the answers. 
II. The Hydroelectric Development Process

\section{A. Introduction}

This section will outline and discuss the SSH development process. While each project will encounter unique problems, the process described below generally pertains to any ssi project. The hydroelectric development process can be broken down into six sequential steps. These steps, which will be discussed in this section, are:

1. Reconnaissance study

2. Feasibility Study

3. Permits, Licensing, and Exemptions Study

4. Engineering Design

5. Power Purchase Negotiations

6. Construction

7. Operation

B. Reconnaissance study

The political subdivision interested in a hydroelectric project has usually identified one or more potential project sites. The next step after site identification is to undertake a reconnaissance or pre-feasibility study. The reconnaissance study is a preliminary investigation to determine if it is worthwhile to undertake a full scale feasibility study. The study is a relatively complete small scale feasibility investigation in which rough estimates of benefits and costs are made and other critical issues are appraised. One critical issue that should be addressed at this time is the legal authority of the political subdivision to develop the site itself, to develop the site in conjunction with others and to finance the development. An unfavorable reconnaissance study would stop further consideration of the project and would prevent resources from being wasted on an unfavorable feasibility study. A favorable reconnaissance study indicates that the political subdivision should proceed to a full scale feasibility study. Even in those cases where the political subdivision does not know whether it will develop the site itself there are good reasons to proceed with the feasibility study. Information from the feasibility study will allow the public entity to more accurately evaluate alternative development strategies and may elicit better offers from bidders as the better information reduces their uncertainty.

The reconnaissance study also provides information that is necessary in the preparation of the preliminary permit application. Although a preliminary permit is not required for a license application, obtaining a permit from FERC secures priority for the project license while the permittee completes the feasibility and licensing studies. As with license applications, FERC must give preference in awarding permits to state or municipal applicants if the applications are otherwise equal.

The preliminary permit application consists of an initial statement and four exhibits. The initial statement identifies the applicant, the nature and location of the proposed project and the proposed term of the permit. Exhibit I contains a physical description of the project, including its principal structure and any lands of the United states enclosed by the project boundary. Exhibit 2 is a study plan of any proposed studies and tests and a statement pertaining to any new roads required to conduct such studies. Projects which require new dam construction must, as part of Exhibit 2, submit a detailed workplan, schedule, and information on the minimization of the study's environmental impacts. Exhibit 3 is a statement of the cost and financing of the project, including a description of a proposed market tor the power and the expected revenues froin the sale. Exhibit 4 is a map of the proposed project's location. Preliminary permits are valid for a period not to exceed three years, are non-transferable and may be cancelled by order of the Commission if the permittee fails to comply with the conditions of the permit.l

The reconnaissance study and preliminary permit for a site smaller than 25 MW 
should take 30 to 90 days to complete and cost from $\$ 2,000$ to $\$ 15,000$. For developers with a technical background the following manuals may allow the developer to do some of the work, thus reducing the cost.

$\frac{\text { A Guide for Small Hydroelectric Development, United States Department of }}{\text { Energy, Idaho Operations Office, March } 1980 .}$

Feasibility Studies for Small Scale Hydropower Additions: A Guide Manual, United States Army Corps of Engineers, July, 1979.

Reconnaissance Evaluation of Small, Low-Head Hydroelectric Installations, United States Department of the Interior, Water and Power Resources Service, Engineering and Research Center, Denver, Co., July 1, 1980.

Site Owner's Manual for Small Scale Hydropower Development, New York State Energy Research and Development Authority, March, 1980.

\section{Feasibility Study}

A professionally prepared feasibility study should be undertaken if the reconnaissance study is favorable and if the preliminary permit is expected to be approved. In the feasibility study the engineering, economic, legal, and environmental issues affecting the project are exanined in detail and a course of action is recommended. The feasibility study determines whether or not the project should be undertaken and, if the project is undertaken, begins the necessary procedures. suggestions for financing the feasibility study are given in section IV. B. below.

The feasibility study usually begins with an engineering study of the site by an engineering firm with experience in small scale hydroelectric projects. This study determines the project's feasibility from an engineering standpoint and provides estimates of construction and operating costs.

As a second portion of the feasibility study, estimates of revenues from electric sales should be made. If the capacity and power of the system is to be sold to a utility, the utility should be contacted to discuss rates and other details of the power contract. At this point it is also appropriate to estimate financing cost based either on the experience of the political subdivision or through consultations with investment bankers or others with financial expertise. Further analysis of the question of the legal authority of the political subdivision to participate in development is also essential at this stage.

Once the potential developer has estimates of revenues, construction, operating and financing costs then net present value or internal rate of return, or cost benefit calculations can be used to determine if the project is feasible. It should be noted that a feasible project according to these calculations may encounter cash flow difficulties in the early years of the project and thus would encounter serious financing problems. Hence, financing considerations are critical even when the project looks "feasible" from the standpoint of a cost-benefit calculation.

In addition to the engineering and financial studies, the potential environmental impacts and impacts on alternative uses of the site such as recreation, flood control and water supply should be throughly considered. In particular, the feasibility study should identify problem areas such as migratory $f i s h$, white water and competing demands on the water which would make development of the site less attractive.

\section{Permits, Licensing, and Exemptions}

Under the Federal Power Act, FERC has extensive jurisdiction over hydroelectric projects. If a project will be connected to the system of an electric utility which is in turn connected to an interstate grid system or if the project is located on or will affect a navigable waterway, FERC will have jurisdiciton over the project. 2 with the exception of certain parts of Texas and Alaska and islands such as Hawai and Puerto Rico, all electric utility"systems in the unites states are interconnected to an interstate grid. The courts and FERC have also prescribed an "historic" test for purposes of determining navigability, i.e., if the waterway has been used for water borne commerce sometime in the past or can be used for commerce with improvements, it 
will be deemer navigable. 3

Given that almost all SSH projects in the continental United States will be subject to FERC jurisdiction, the next question is what is a developer required to do to comply with FERC regulations. Ideally, the feasibility study described above will be conducted in such a manner and yield information so as to make compliance with FERC regulations easier and less costly. Municipal managers and their county and district

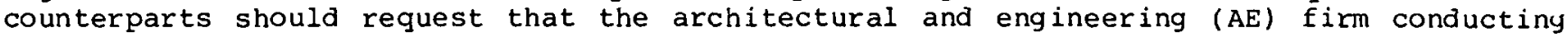
the feasibility studies address questions raised by FERC regulations. Many AE firms experienced in SSH projects will offer such services as part of services provided for the feasibility study.

FERC issues preliminary permits, two kinds of licenses and two kinds of exemptions for SSH projects. As discussed above, prelininary permits provide the holder of the permit the right of access to a site for purposes of studying the site for the period of the permit (no longer than three years) and give the holder priority to the site if the holder should apply for a license within the permit period. political subdivisions are given a preference over other competing permit applicants so long as the application of the political subdivision is equal to that of other competing applicants.

The licenses issued by FERC are called a "Minor Project" license and a license for a "Major Project at an Existing Site." Minor project licenses apply to projects of 1.5 MWs or less at existing sites or new projects of 1.5 MWs or less. FERC has adopted a "short form" license application for minor projects. The short form license process requires the applicant to consult with state, local and federal regulatory agencies in advance of filing the license application. The most important information needed for filing a short form license application is information and data concerning the environmental impact of the project. This information is compiled in an "Environmental Report" and appended to the application.4 The AE firm or other firm undertaking the feasibility study should be fully cognizant of the information requested in the Environmental Report and should undertake to acquire the necessary information or, if necessary, advise the developer at the earliest possible moment that additional environmental studies expertise is needed to complete the feasibility study and the license application.

The other license applicable to $\mathrm{SSH}$ is the license for a major project at an existing site and, as the name indicates, applies to all hydroelectric projects which intend to use an existing impoundment structure. As with the short form license, the most important information to obtain for a major project at an existing site concerns the effect of the project on the environment. Again, ideally information about the environmental effects of the project obtained in the course of the feasibility study should be useful in completing the environmental exhibit (Exhibit "E"). Exhibit E must be appended to the application for a license for a major project at an existiny site.5

Political subdivisions are granted a preference under the Federal Power Act for hydroelectric licenses. As with preliminary permits, if the plans for development of the project by the political subdivision are equal to the plans of the competing license applicants, the political subdivision, under the preference, will be awarded the license. The preference confers a significant advantage in ssH development on political subdivisions and, for this reason, makes them attractive partners in development with private entrepreneurs. However, FERC has recently raised a question as to whether the "public preference" applies in situations where there is joint public-private development. The question and the relationship among competitors for ssH site development will be discussed in more detail below. See Section F, Chapter III, infra.

There are two types of exemptions that are issued by FERC that also are applicable to SSH development by political subdivisions. The two exemptions are the "conduit hydro" exemption and the case by case 5 MW exemption. 6

There are common features of hnth types. In cxempliull is an authorization issued Ly FERL to a developer which exempts the developer from various provisions of federal law and regulation (i.e., provisions of the Federal Power Act). Once a developer receives an exemption, the developer must proceed with development of the project subject to the conditions of the exemption certificate and applicable state and local law. A developer with an exemption need not obtain a license from FERC for the project. 
The advantages of exemption are:

1. the exemption application should be less costly to prepare than a license application;

2. FERC need not formally act on the exemption, rather if FERC fails to act after a specified period of time the exemption is automatically granted; and

3. under certain circunstances an exemption may protect the owner of a site from competing applications for permits and licenses.

The disadvantages of an exemption are:

1. exemption applicants will be forced to deal with state regulators without FERC participation and assistance; and

2. comments made by the federal Fish and wildlife service (Fws) and state fish and game agencies with respect to any exemption application become conditions of the exemption. The distinction here is that comments inade by Fws and state fish and game agencies with respect to license applications can be accepted, modified or rejected by FERC whereas comments on an exemption application automatically become conditions of the exemption and the project.

Given the common features of both types of exemption, it is also necessary to point out their differences. The "conduit hydro" exemption applies to manmade facilities (e.g., irrigation canals, water mains) which are not an integral part of a dam. To be eligible for the conduit hydro exemption the site must have 15 MW of capacity or less and not be located on federal lands. An application for a conduit hydro exemption contains a brief initial statement identifying the project and developer and four exhibits, including an environmental report. Failure of FERC to act on the application within 90 days after it is accepted for filing results in the grant of the exemption.

An exemption for a specific project of 5 MWs or less (case by case 5 MW exemption) is available to the owner of a site which has 5 MWs or less and utilizes an existing impoundment structure. The application is almost identical to the conduit hydro exemption (i.e., a statement and four exhibits). If FERC does not act within 120 days on an accepted 5 MW exemption application, the exemption is automatically granted.

Both the conduit and 5 MW exemptions are subject to standard conditions. The most important condition for the $5 \mathrm{MW}$ exemption is that construction of the project must have begun within eighteen months of issuance of the exemption. Both types of exempted projects must also comply with the conditions imposed by the federal Fish and wildife Service and state fish and game agencies.

The previous discussion concerning the various pernits, licenses and exemptions from FERC has alluded to the "municipal preference" and priority status of certain applications. Because the timing of an application and the status of an applicant may be critical to the ability of a developer to obtain a FERC permit, license or exemption, the FERC rules on preferences and priorities should be fully discussed. This section will lay out some basic rules on preferences and priorities. However, experienced legal counsel should be consulted in any situation in which there is a question concerning preferences or priorities. Delays and improper or deficient filings with FERC may result in the loss of a valuable site.

It must be remembered that the Federal Power Act and FERC acting pursuant to it, decides who gets the site as well as how the site should be developed. The Act and FERC decide who gets the site notwithstanding another person "owns" the site and the necessary water rights under state law. Accordingly the permitting, licensing and exemption process of FERC establishes rules for making the choice between competing developers.

For political subdivisions the FERC rules on "who gets" are relatively simple. Political subdivisions are given the preference to a permit or license.7 In other words, all applications for permits or licenses being equal, the political subdivision will be given the permit or license. The FERC rules permit the political subdivision 
latitude in amending its application to be equal to that of a competing applicant.8

FERC rules favor a license application over a preliminary permit application because the former indicates an intention to develop the site as opposed to studyiny it. 9

The Federal Power Act and FERC rules favor priority applicants over other applicants. A priority applicant is a person who holds a preliminary pernit and has filed an application for a license or exemption during the permit period.10

Finally, the new 5 MW exemption rules protect a site owner in a number of situations. FERC will not consider a preliminary permit or license application on a site for which the owner has previously filed an exemption application. However, an exemption application will not be accepted if there is a previously filed license application by: a priority applicant (one who has a preliminary permit on the site and has filed a license application within the permit period). Similarly, an exemption application will not be granted in the face of a previously filed license application unless the plans for development under the exemption application are better than plans proposed for the license application. Remember only site owners or persons with substantial property interests in the site can file for the 5 MW exemption. Political subdivisions do not have significant advantages over "exemption-owner" applicants and, in fact, the municipal preference gives way to the owner's "preference" for purposes of the exemption. 11

From the foregoing, it is obvious that employees of political subdivisions should be aware of the various rules and regulations of FERC concerning SSH development. At any given time a political subdivision may be confronted by the option to seek a preliminary permit, a license or an exemption or to do nothing. The FERC rules and regulations are most important for they will determine who gets to develop a site. Moreover, the selection of the particular procedure will affect the costs of the project and the time it takes to develop the project. If there is a question concerning preferential or priority status or choice of the FERC procedure, competent legal advice should be obtained.

There are at least two documents which may be helpful in this area. They are: Hydropower Licenses and Preliminary Permits, Office of Electric Power Regulation, Federal Energy Regulatory Commission, Washington, D.C. (Permit and License Regulations with forms and helpful Appendices)

(GPO: 1980 0-324-164/6365).

Federal Legal obstacles and Incentives to the Development of Small Scale Hydroelectric Power, Energy Law Institute, Concord, New Hampshire, July, 1980 (A description and analysis of the federal regulatory system affecting SSH; see pp. 13-58) (NTIS \# DOE/RA/04934-29).

\section{E. Engineering}

The detailed engineering of the project, which includes investigating and surveying the site, typically requires six months to one year. A few months before the end of the engineering study the developer should have detailed projections of the project cost and final project drawings. These detailed cost projections and final drawings can now be used by the developer to obtain construction bids and lony term financing. The cost of engineering investigation, design, and construction supervision usually ranges from 5 to 15 percent of the project's cost. Given the magnitude of the costs associated with obtaining this detailed information, there may be problems encountered in financing these costs at this relatively early stage in the project. These problems will be addressed in Chapter IV, Section B, infra., and methods will be suggested for financing these costs.

\section{F. Power Contract Negotiations}

With the knowledge of the project costs gleaned from the feasibility and advanced design and engineering studies the political subdivision and its employees should commence formal negotiations with the local utility for the sale of power.

As discussed very briefly in the Introductory section, a relatively new federal 
law, PURPA, requires electric utilities to purchase the output from ssH projects at rates that are just and reasonable. The rates for purchase are to be set by state regulatory commissions for regulated electric utilities. Public utilities and rural electric cooperatives, where they are not regulated, set the price for themselves.12 FERC has issued regulations establishing standards to be followed by regulatory commissions and unregulated utilities in setting rates. These standards require that the rates equal the "avoided" costs of the purchasing utility. In other words the rates for the purchase of SSH power shall be equal to the costs that the purchasing utility otherwise would have incurred had it supplied the power in the absence of the power from the SSH facility. States and unregulated utilities must make substantial progress in implementing this new law and its regulations by March 20, 1981.13

In the context of PURPA and its regulation, the first question a political subdivision will address is whether it has the authority to and desires to sell the power from its SSH project to the local electric utility or use it for its schools, public or municipal buildings or some other public or municipal purpose. Whether the political subdivision has the requisite legal authority to sell to the local utility must be addressed by the solicitor for the subdivision and/or competent bond counsel. Aside from certain federal tax considerations which will be discussed below, greater revenues will probably be generated for the project if all or substantially all of the power is sold to the electric utility and not used internally ("sold" by political subdivision to itself). The reason for the higher revenues is that the avoided cost rate set by a state regulatory commission or the unregulated utility will, in most cases, be higher than the rates paid by the political subdivision to the electric utility for electric service for public needs.

Assuming the political subdivision has the requisite legal authority and has chosen to sell the output to the electric utility to maximize project revenues, the next question is does the political subdivision rely on the PURPA rates established by the state regulatory commission or unregulated utility or negotiate a long term purchase power contract with the local utility. In answering this question, it would be well to note that the rates set under PURPA may fluctuate and will be perceived by financing institutions as uncertain. Accordingly, financing institutions will be reluctant to enter into long term loan agreements with SSH developers unless there is some security for the loan other than the uncertain flow of revenues under PURPA rates. Full faith and credit (general obligation or "G.O.") obligations issued by the political subdivision which pledge the taxing authority of the subdivision in payment of the debt service (interest and principal) would provide the needed security as would a federal or state guarantee of the loan payments. These securities, however, may be difficult to obtain.

Federal and state guarantees may not be available, especially in light of the recent curtailment of a number of federal spending programs. The process of issuing general obligation ("G.O.") bonds may be cumbersome (in some instances requiring two consecutive referenda) and too time consuming. Moreover, there may be a serious question of the legal authority of the subdivision to utilize G.O. bonds to finance such a project. Finally, practically every political subdivision with authority to issue G.O. bonds is limited by statutorily or constitutionally imposed ceilings on G.O. debt. If the debt ceiling is exceeded by the G.O. bond issue for the sSH project, then, of course, G.O. bonding is unavailable.

Given the need to obtain financing for the project and the attendant need for a secure revenue flow, the availability and terms and conditions of a contract with the local utility for purchasing SSH power become critical to project success. A long term power contract, among other things, can provide the additional security needed to enable the project to be financed.

However, there are difficulties in financing projects based on long term purchase contracts as well. Since the security for the financing is the contract with the utility, the credit rating of the purchasing utility will be critical to the cost and availability of debt financing. If the credit rating of the purchasing utility is very weak, G.0. debt financing may be much cheaper than reliance on a purchase power contract.

Assuming that a purchase power contract is chosen as the means for providing the security, it is most helpful, even necessary, to have available a person with knowledge 
of the electric power business for purposes of negotiating with the electric utility. It is also important to know the costs and general condition of the electric utility. Electric utilities must file numerous reports, such as annual reports, reports on load growth, etc., with the state utility commission or FERC which reports should be consulted in advance of any negotiations. In addition the company will have filed data for purposes of establishing the PURPA rate or, more importantly, the state regulatory cominsion or unregulated utility may have established a PURPA rate. From the data filed or the rate itself, the upper limits of a contract price with the purchasing utility can be pegged. The lower limit of any contract price is the levelized cost (including payment of debt service) of producing power for the life of the plant. Within these limits a variety of arrangements can be negotiated, including contracts which provide for automatic price adjustments to reflect increases or decreases in costs. The arrangement which will reduce the financing risks the most would be a "Hell or High Water" contract pursuant to which the purchasing utility would agree to pay, at the very least, debt service notwithstanding the fact that the project was not producing power:14 However, in exchange for this commitinent from the purchasing utility it is likely that the SSH project would receive a rate much lower than the PURPA rate set by the appropriate regulatory authority. In short, the greater security pledged by the purchasing utility to guarantee the stream of payments for the power, the easier will be the project financing but the lower the purchase power price. In some instances where equity participation is obtained, the political subdivision may obtain a higher purchase price. In these situations the PURPA rate may yield revenues substantially in excess of the annual debt service payments (i.e., the coverage ratios are high). Given the large margin of coverage, financing institutions may be willing to finance a project based on an uncertain flow of future revenues.

For a more detailed discussion of power contract negotiations in very similar contexts, the reader is referred to the Financing Private SSH, pp. 83-86.

\section{G. Construction}

Project construction, including the manufacture and installation of equipment, usually takes one to three years depending on the complexity of the project. For projects of $5 \mathrm{MW}$ capacity or less that have received an exemption from licensing the exemption will be revoked if construction has not begun within eighteen months or has not been completed within four years. For licensed projects, the license will be terminated if construction has not commenced within two years or completed within the time fixed by the license unless an extension has been granter. Extensions for the commencement of construction may be granted once but not for longer than two additional years. The period for the completion of construction can be extended if the developer shows that it has proceeded with reasonable diligence.

Usually construction and equipment contracts require an advance payment to the contract of approximately ten percent of the amount of the contract. The equipment supply contract usually requires a payment of eighty percent of the contract amount on delivery. The construction and installation contract payments are made monthly, based on completed construction with the exception of the ten percent retainer which is paid after the construction is determined to be complete and acceptable by the owner or eng ineer. 
III. General Organizational and Business Considerations

\section{A. Introduction}

This section will discuss general considerations to be examined by any political subdivision interested in SSH development. As is readily apparent, a number of arrangements can be made to develop SSH projects. This section will examine the general organizational and business considerations for three scenarios in which the subdivision (1) is the exclusive developer, (2) is a joint venture with a private firm or (3) disposes of its interest in the site to a private developer. The section will also suggest ways whereby the subdivision can evaluate the relative merits of any development scenario.

\section{B. Authorization to Proceed with a SSH Project}

Every political subdivision must examine its charter or enabling legislation in order to determine whether it is authorized to proceed with development of a ssH project. Generaliy, the town solicitor or his/her counterpart is very familiar with the charter or enabling legislation and will be able to render a preliminary opinion on the question. When the financing arrangements for the project are being developed, the financial adviser to the project and/or the underwriters will also require that independent bond counsel render an opinion as to the authorization for the project and its financing. Bonds counsel's fee will be treated as a cost of financing or underwriting and will often be paid out of the proceeds of the issue.

Some of the problems that may be confronted by political subdivisions are that political subdivisions may not be authorized to undertake power or utility projects unless expressly granted such authority by their charter or upon vote of citizens of the subdivision at a special election or town meeting. Many states also have provisions in their state constitutions which bar public expenditures which directly or indirectly aid private, "for profit" enterprises. These provisions may be of particular concern should the subdivision be contemplating a joint venture with a private developer. Some political subdivisions may also not be permitted or expressly authorized to issue revenue bonds (debt instruments secured by project revenues). As noted earlier, if the subdivision is contemplating G.O. financing (assuming it has the authority) such G.o. financing may exceed the subdivision's debt ceiling and hence is prohibited.

If there appear to be any restrictions against a political subdivision proceeding solely or jointly to develop a project, the political subdivision may want to turn the site over to private development. The mechanisms chosen for this latter disposition of a site range from auctioning the site off to negotiating a management contract with a private firm pursuant to which contract the firm agrees to act on behalf of the political subdivision.

\section{Public Ownership and Development}

Assuming the requisite authorization exists, the political subdivision may choose to be the sole owner, developer and operator. Under these circumstances, the financing and other arrangements are straight-forward. The political subdivision would follow the development process described above. At the stage of advanced design and engineering, the political subdivision should initiate discussions with finance and investment advisors. The principal sources of funds would be the sale of revenue bonds or G.o. bonds. As noted previously, revenue bonds are debt instruments whose debt service payments are made from revenues generated by the project. G.O. bonds pledge the taxing authority of the subdivision as security for the project. The financial advisor to the project will or should be able to advise the political subdivision as to the advantages and disadvantages of revenue bond financing as opposed to G.O. bond financing at this stage in the project. Generally, G.O. bonds will be favored if the process of authorization does not involve undue delays and uncertainties and if the debt ceiling of the subdivision is high enough to permit G.O. financing for the project and to avoid impairing the ability of the subdivision in G.O. financing of other essential projects in the future. It bears repeating here that a G.O. financing strategy $g i v e s$ the political subdivision greater bargaining leverage in negotiating the long term power purchase contract with the electric utility. In the event of a stalemate, the political subdivision may even choose to rely on the PuRPA rates set by the regulatory authority since the security for debt service is, in the last analysis, the tax revenues of the 
subdivision.

Revenue bond financing will be favored where the debt ceiling of the subdivision imposes constraints on G.O. financing and the process of authorization is less cumbersome. Revenue bonds may also be favored if the purchasing utility is willing to execute a long term purchase power contract at rates which are very favorable. This situation could occur where the subdivision owns or has access to an "excellent" site (one whose development costs are quite low) and where the avoided costs of the purchasing utility are quite high either as determined by the state regulatory authority or by the political subdivision upon review of the utility's data.

In the event either revenue or G.O. bond financing is used, certain provisions of the Internal Revenue Code make the payments of interest on these bonds to the holders of the bonds, exempt from federal income taxes. In many instances the payments of interest on such bonds will be exempt from state and local income or similar taxes. These provisions make the interest charges on such bonds lower, and at times considerably lower, than non-tax exempt debt securities. With respect to G.O. bonds, the provisons of the Internal Revenue code are straightforward. Since they are issued by a political subdivision and since the security for the bonds is the taxing authority of the subdivision, they are tax exempt. The provisions of the Internal Revenue Code making revenue bonds (as described in the code provisions) tax exempt are a bit nore complicated.

As is discussed more fully below, there are several provisions of the Internal Revenue code that make the interest earned on revenue (i.e.," "industrial development") bonds tax free. The provisions of the code, discussed below, which can be used to assure tax exempt status are the small issue exemptions, the "local furnishing" of electricity exemption and the COWPTA exemption. As discussed earlier, the power purchase contract would assure debt service payments. See Chapter IV, infra, "Financing and Sources of Funds."

\section{Joint Private and Public Ownership or Development}

Assuming state or local law permits, the political subdivision may consider joint development with a private development firm, the local investor owned utility or another political subdivision (e.g., a town-county' development).

The advantages of such an arrangement are several and accrue to both parties. For the political subdivision, the private entity will provide expertise in SSH development and operation and probably some equity for the project, and, given the equity. contribution, will make it easier for the political subdivision to obtain tax exempt revenue bond financing for the project. Assuming the political subdivision holds the FERC license, the private developer or the investor owned utility has the advantage of the municipal "preference," the political "clout" of the political subdivision in dealing with the state regulatory system and tax exempt debt financing (financing at lower interest rates) for a portion of the project. There is an additional stimulus for the private entity (developer or utility) in that it also will receive a 108 tax credit based on its total investment in tangible, depreciable personal property of the project, an 118 tax credit based on its investment in that portion of the project not financed by the exempt revenue bonds, a deduction from its taxable income for business losses in the early years of the project and ultimately a share of the "profits" of the project either when it starts to generate net revenues or when the private entity disposes of its interest in the project at a capital gain. For a more detailed discussion of the tax treatment of private investments in SSH projects, the reader is advised to consult the Financing Private SSH, pp. 36-54.

The "deal" between a political subdivision and a private developer can be arranged in any number of ways. It is suggested that, should a political subdivision consider a joint project, they consult expert legal and financing advisors and, at the very least, circulate a "Request for Proposal" (RFP) with the business community. An RFP is merely a solicitation by the subdivision for proposals for, in this case, a joint development. The RFP should describe the project, the general nature of the subdivision's interest in a joint project, its proposed relationship with the private firm (e.g., lessor-lessee, joint venture etc.), and should be circulated as widely as possible. It should contain a due date for proposals, a suggested format for proposals and a statement that the political subdivision reserves the right to reject all proposals. 
Depending on the status of the SSH project, the RFP may contain a requirement that the selected developer undertake a feasibility study and procure the necessary licenses. If the feasibility study has been completed and a license or permit application has been submitted, the RFP will request only the plans for development and operation.

In awarding the proposal, employees of the political subdivision probably will be required to evaluate two or more proposals. Here again, assistance from qualified finance persons, lawyers and engineers will be most helpful, if not necessary. $A$ team to assist in the evaluation of the proposals can be easily assembled and per diem consulting fees arranged at reasonable rates.

As will be discussed more fully below, there are methods which can be employed to enable a political subaivision to assess the relative merits of a number of competing proposals. Beyond the basic and most important question of the revenues made available to the subdivision by the joint project, the experience of the private development team must be known and evaluated, and the source of funds and commitments of outside financing institutions should also be known. The assessment of the relative values of various revenue streams coming to the subdivision will be discussed in subsection G, infra.

\section{E. Disposition of the site - the Political Subdivision as a Passive Participant}

For a variety of reasons political subdivisions may not wish to or cannot actively participate in the development of a SSH project. Yet these subdivisions may own a site or sites and may be confronted with annual maintenance and insurance expenses or, in some instances, an order by a state agency to repair or breach the existing site. In this situation it is of obvious advantage to develop ss power at the site (assuming the feasibility study determines the project at the site is feasible) by a private developer or some other public entity. If development should occur the developer will incur the annual maintenance and insurance expense and will be required to maintain a safe dam and civil works, costs which the subdivision would otherwise have had to bear. Moreover, the subdivision, depending on the arrangement with the developer, should also receive revenue in the form of a lump sum payment for the site, rent over a period of years or tax revenues from taxes levied on the site.

Disposition of a site owned by a political subdivision can take a variety of forms. There can be an outright sale at auction, a sale of an option to purchase the site at auction, a lease resulting from a bidding system, or a management and development contract resulting from a competitive proposal system, among other forms. The important factor to bear in mind in any plan for disposition of a site is that the political subdivision should choose the plan from a number of alternative proposals. In short, some type of competitive bid or solicitation system should be devised by the personnel of the political subdivision.

The RFP system described for joint projects in subsection D, supra, is probably the most workable competitive system. Under that system proposers can be $g i v e n$ some flexibility in their plans for development and need not or should not be consigned to rigid price or bid formulas. The RFP, assuning state and local law permits, can solicit a bid for sale of the site based on a lump sum payment and at the same time solicit proposals for rental payments or management contracts. Given the flexible nature of an RFP, the subdivision may accept proposals which differ in form but which can be evaluated, as will be discussed below, on a comparative basis.

Managers and others interested in public development of SSH may wish to review the materials developed by the State of New Hampshire for the leasing system devised by that state for sites owned by the New Hampshire water Resources Board. See:

Invitation For Bids No. WRB-H-2 (Kelly's Falls Dam)

N.H. Water Resources Board

37 Pleasant St.

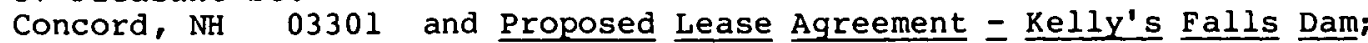


Invitation For Bids No. WRB-H-l (Sewalls Falls Dam)

N.H. Water Resources Board

37 Pleasant Street

Concord, $\mathrm{NH} 03301$ and

Proposed Lease Agreement $=$ Sewalls Falls Dam.

Copies of these materials may be obtained from Vern Knowlton, P.E. at the N.H. Water Resources Board at the above address.

\section{F. Caveats for FERC Licenses and Exemptions}

As will be recalled from the earlier discussion of FERC pennits, licenses and exemptions (Chapter II, section D), almost every SSH site will be subject to FERC jurisdiction and will, therefore, need a FERC license or exemption. There is one difficulty, based on an unresolved legal question, which must be noted.

As discussed in sections $C$ and $D$, supra, political subdivisions may jointly develop a project or arrange to have their sites developed for them. To the extent political subdivisions are given the "municipal" preference for licenses, it is of obvious advantage to have the political subdivision apply for the license and have the license issued to it. Under these scenarios the private developer would develop and operate the project under an agreement with the political subdivision but the political subdivision would ultimately be bound to perform the conditions and terms of the license received from FERC.

A question has recently been raised by a private utility company to FERC of whether a political subdivision holding a license under an arrangement with another private entity qualifies for the municipal preference. The private utility has urged that the "municipal preference" does not apply in these situations. If there is no municipal preference under these circumstances it may become difficult, if not impossible, for a municipal which wants to develop its site to obtain a license when there are other competing license applicants for the same site.

In response to the questions raised, FERC has recently issued a Notice of Inquiry requesting comments from interested parties as to whether political subdivisions are entitled to the municipal preference in situations where a municipality (political subdivision) and a non-municipal entity (e.g., private developer) file a joint application for a preliminary permit.15 FERC has further requested comments as to whether, in the situations of joint applications, the municipality should be required to have a minimum percentage of ownership in the site for there to be a municipal preference. While it is not clear at this writing what the results of this inquiry will be, the Notice of Inquiry is evidence of the serious concern, and hence, difficulty FERC is experiencing with the question. It would appear that political subdivisions which own sites and which have the authority under state or local law to develop power at those sites would be in a good position to secure the municipal preference for the situation where they are participating with a private developer. In this latter situation it may be wise for the subdivision to require the private developer to prepare a single permit or license application in the name of and on behalf of the political subdivision. Under these circumstances, the political subdivision will be the sole permittee or licensee and as such will be bound to the terms of the permit or license. The political subdivision, in turn, can bind the private developer to the terms and conditions of the license by the contract, lease or other legally enforceable arrangement that the political subdivision has with the private developer. However, it must be emphasized that the results of the Notice of Inquiry and any subsequent decision by FERC are highly uncertain. No arrangement, including the arrangement described above, can guarantee at this writing that the political subdivision will obtain the "municipal preference" for a permit or license.

A partial answer to this problem is that, where possible, the political subdivision should use the $5 \mathrm{MW}$ or conduit hydro exemptions. As noted earlier, the 5 MW exemption gives owners a "preference" over preliminary permit applications and later filed license applications. However, the advantages of an exemption will not protect a political subdivision which wants to develop a site in excess of 5 MWs or when a license application has been filed on the site prior to the filing by the political subdivision of an exemption application. 
Given the unresolved legal question and the limited protections afforded by exemptions, it is imperative that employees of political subdivisions take the necessary steps to protect their SSH sites from competing permit and license applications. As a general rule, filing an application (permit, exemption or license) first in time gives the applicant an advantage. If there is interest expressed in a sSH site, the political subdivision would be wise to, at least, file a preliminary permit application on its site. In all events where there are questions, competent legal counsel should be promptly consulted.

\section{G. How to Evaluate Alternative Proposals for Development}

This section will describe a method for evaluating alternative development proposals and will give examples of how the method should be used. As noted above, the political subdivision will be confronted by alternatives for development. The problem is how to compare the benefits of one proposal with other proposals which differ in substantial ways. While there are unquantifiable variables involved in any development proposal (e.g... the experience of a particular proposer's management team, the values to the community of maintaining control of ownership of its resource as opposed to "selling" the site), the revenues from the variety of proposals, no matter how they are obtained, can be compared. The method for comparison is to perform a simple present value calculation of the net cash flows to be obtained under each developinent scenario. Once the present value of the revenues net cash flows is determined, the development scenario which yields the highest net present value would be determined.

The difficulties with this evaluation method are the age-old problems of selecting the discount rate; properly quantifying the future "net" revenues of a project which quantification, in turn, depends on estimates of future electric power costs, maintenance expenses, taxes, etc.; and the inability of the method to ascribe values to such intangibles as community ownership and community employment, among others. However, it is submitted that a comparative present value calculation of varying development scenarios is fundamental to any public development decision. Once such a calculation is made, then the more difficult, "political and social" factors may be considered in making the final choice.

Present value analysis is a method that is used to compare the value of payments made at different times by adjusting these payments for the time value of money. If money can earn interest then a dollar received today is worth more than a dollar received in the future. Thus, in order to meaningfully compare two or more payment streams involving payments made at differnt times the value of these payment streams must be calculated at a common time. This is accomplished by discounting the value of the future payments to the present, which means that the present or capitalized value of each payment stream is calculated. Readers who are not familar with the discounting or present value calculation can find a detailed explanation in virtually any finance, investment managerial economics or engineering economics text, for example:

Levy, H. And Sarnat, M. Capital Investment and Financial Decisions, Prentice Hall, Englewood Cliffs, New Jersey, 1978 .

Pappas, J. and Brigham, E. Managerial Economics, Third Edition, Dryden Press, Hinsdale, Illinois, 1979 .

In order to show how present value analysis can be used to evaluate various development strategies, four development scenarios at a hypothetical site will be analyzed below. These four cases will examine how the public entity should determine whether to develop the site itself, sell the site, lease the site, or develop the site jointly.

Assume that the results of a reconnaissance study of the site indicate that a 1.2 MW capacity turbine could be installed and would be expected to generate. 6.5 ... million kwh per year for 50 years after the site comes on line in 1985 . The public entity expects to sell the electric energy at 6.0 cents/kwh thus earning gross revenues of $\$ 390,000$ per year after 1985. The expected costs of the development and operation of the facility in each year are reported in Table $I$. If the public entity develops the site itself, it expects to finance the development with 30 year revenue bonds at an interest rate of 11 $1 / 28$. 


\section{Public Ownership and Development}

In the first development scenario it is assumed that the public entity develops the site itself. The net present value of the development in this scenario is calculated by summing the present value of the estimated net cash flows from the project and the present value of the estimated site value in 2035 (assumed to be $\$ 400,000$ ) then deducting the present value of the 1981-1984 development cost. Calculating these present values for 1981 at the public entity's discount rate using the entity's financing rate of $111 / 2 \%$ of yields:

$$
\begin{aligned}
\text { Present Value of } 1985-2034 \text { Net Cash Flows } & =\begin{array}{r}
\$, 736,524 \\
+\quad \text { Present Value of } 2035 \text { Site Value }
\end{array} \\
-\quad \text { Present Value of } 1981-1984 \text { Development Cost }= & 1,444,508 \\
& \text { Net Present Value of Self-Developed Project }=\$ 293,136 .
\end{aligned}
$$

\section{Sale of Site}

In the second scenario a developer has offered to purchase the site for $\$ 250,000$ in 1981. The developer will pay a property tax at a rate of 3 mills on the purchase price of the site from 1981 to 1984 and on the purchase price and the value of the installed equipment $(\$ 1,500,000)$ from 1985 to 2035 . The net present value of the earnings from the site in 1981 discounted at $111 / 2816$ is:

$$
\begin{array}{llr}
\text { Present Value of Payment for the Site } & = & \begin{array}{r}
\$ 250,000 \\
+ \text { Present Value of } 1981-1984 \text { Taxes }
\end{array} \\
+ \text { Present Value of } 1985-2035 \text { Taxes } & = & 2,302 \\
& \text { Net Present Value of Selling the Site } & =
\end{array}
$$

Since the net present value of this alternative is lower than self-development the site should not be sold.

\section{Lease of Site}

In the third scenario a developer offers to lease the site for 50 years from 1981 to 2031 , after which the site reverts to the public entity. The developer is willing to pay a lease of $\$ 30,000$ per year and the site is expected to be worth $\$ 400,000$ in 2031 . The developer is expected to pay property taxes at the rate of $3 \mathrm{mills}$ on the value of the installed equipment $(\$ 1,500,000)$ from 1985 to 2031 . The net present value in 1981 discounted at $11.5 \%$ is:

$$
\begin{array}{lllr}
\text { Present Value of Lease Payments 1981-2031 } & = & \$ 259,741 \\
+ \text { Present Value of Taxes 1985-2031 } & = & 25,148 \\
+\quad \text { Present Value of } 2031 \text { Site Value } & = & 1,731 \\
& \text { Net Present Value of Leasing the Site } & = & \$ 286,620
\end{array}
$$

Since the net present value of leasing the site is lower than the net present value of self-development the public entity should not lease the site.

\section{Joint Development}

In the final scenario a developer offers to develop the site jointly with the public entity. The public entity will receive one-half of the net revenues from the sale of electricity plus property taxes at a rate of 3 mills on the value of the installed equipment if it allows the site to be used until 2035 and provides $\$ 750,000$ in capital in 1983. The site will revert to the public entity in 2035 . The net present value of this alternative is calculated by summing the present value of one-half the gross revenues from 1985 to 2035, the present value of the taxes from 1985 to 2035, and the present value of the site in 2035 then deducting the present value of the $\$ 750,000$ provided in 1983. These figures for 1981 discounted at $11 \mathrm{l} / 28$ are: 


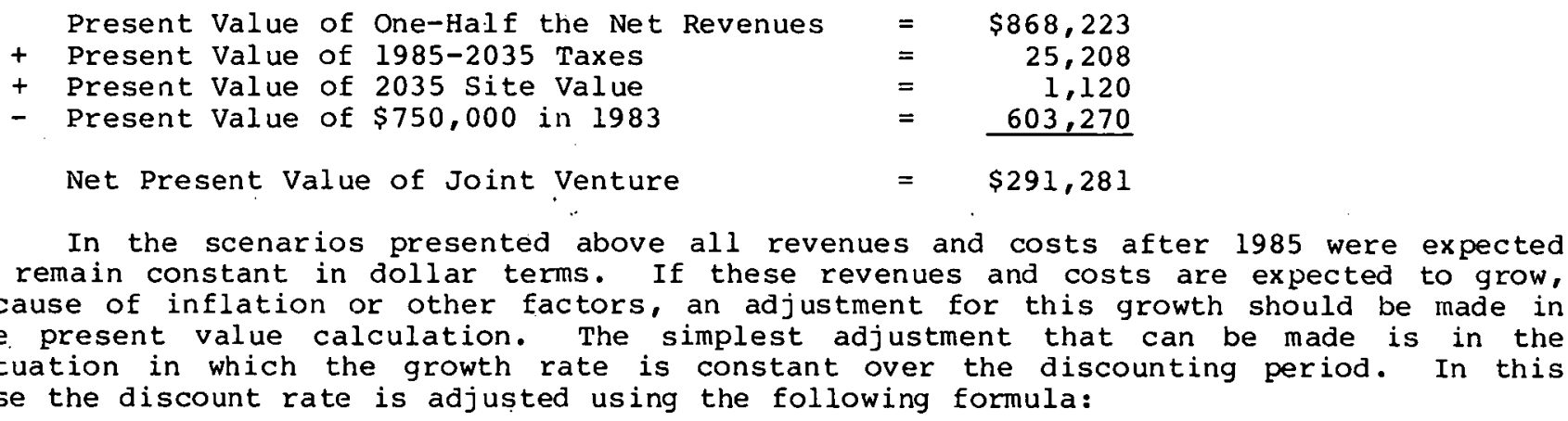

$$
\begin{aligned}
& \text { Adjusted } \\
& \text { Discount } \\
& \text { Rate }
\end{aligned}=\frac{1+\text { unadjusted discount rate }}{1+\text { expected growth rate }}-1 .
$$

The discount and growth rates should be expressed in decimal terms. For example, if the unadjusted discount rate is $11.5 \%$ and revenues are expected to grow at $5 \%$ per year the adjusted discount rate would be:

$$
1.115 / 1.05-1=.0619 \text { or } 6.198 \text {. }
$$

In the above examples the development strategy was determined solely on the basis of net present value. In practice, other factors that are not so easily quantified should be considered as well. In particular, the developer's competence and the impact of his plans on the community should be assessed. When the net present value estimates of the alternative development strategies are nearly equal, the developer's competence together with political and social considerations, would be the major factors in making the final decision. The net present value analysis is only a technique to aid the decision maker; it is not a technique to be followed blindly. 
Table 1

Revenues and Costs of Hypothetical 1.2 Megawatt Development

\begin{tabular}{|c|c|c|c|c|c|}
\hline Year & 1981 & 1982 & 1983 & 1984 & $\begin{array}{c}1985 \\
\text { to } \\
2035 \\
\end{array}$ \\
\hline Project Revenue & 0 & 0 & 0 & 0 & 390,000 \\
\hline \multicolumn{6}{|l|}{ Project Costs } \\
\hline Reconnaissance Study & 2,000 & 0 & 0 & 0 & 0 \\
\hline Feasibility study & 15,000 & 0 & 0 & 0 & 0 \\
\hline Management & 15,000 & 25,000 & 25,000 & 25,000 & 0 \\
\hline License Application & 0 & 8,000 & 0 & 0 & 0 \\
\hline Other Legal & 0 & 5,000 & 0 & 0 & 0 \\
\hline Financing Cost & 0 & 50,000 & 0 & 0 & 0 \\
\hline Detailed Engineering & 0 & 150,000 & 0 & 0 & 0 \\
\hline Installed Equipment & 0 & 0 & 950,000 & 550,000 & 0 \\
\hline General Adminstration & 0 & 0 & 0 & 0 & 15,000 \\
\hline $\begin{array}{l}\text { Operation and } \\
\text { Maintenance }\end{array}$ & 0 & 0 & 0 & 0 & 50,000 \\
\hline Insurance & 0 & 0 & 0 & 0 & 15,000 \\
\hline Total Cost & 32,000 & 238,000 & 975,000 & 575,000 & 80,000 \\
\hline Net Cash Flow* & $(32,000)$ & $(238,000)$ & $(975,000)$ & $(575,000)$ & 310,000 \\
\hline
\end{tabular}

*No deduction has been made for interest or debt service payments. 


\section{Financing and Sources of Funds}

\section{A. Introduction}

Since at least $80 \%$ of the annual cost of a hydroelectric project consists of interest payments and capital amortization expenses, it is important that the political subdivision selects a financing strategy that minimizes the cost of financing the project. In this section the sources of funds available to the political subdivision will be discussed to aid in determining the best financing strategy. In many cases no single source of funds will minimize financing costs. Thus the political subdivision, with professional assistance, if possible, will need to find that combination of financing methods which minimizes the cost of financing the project.

\section{B. Financing Initial Project Costs}

One of the major aspects of sound financial planning is the timing of the financing issue and the problem of matching critical project requirements for funds with available financing mechanisms. Because of relatively long lead times between planning and construction of SSH projects and the operation of SSH projects (flow of revenues), costs of any magnitude confronted in the planning stages of the project can be particularly troublesome.

This part of the manual will discuss the situation in which the political subdivision, for any number of reasons, chooses to "go it alone", i.e., develop the project without any participation by another entity as a joint venturer, lessee, or purchaser. In these latter situations the arrangements with the private joint venturer and lessee can easily be structured so as to require the private participant to obtain the requisite funds to meet initial project costs. In the situation where the site is sold outright, presumably the purchaser will have the requisite funds to meet initial project costs. For the readers who are interested in the mechanisms available to private developers for the funding of initial project costs, their attention is directed to Financing Private SSH, pp. 61-67.

With respect to the situation where the political subdivision is the sole developer there are a number of options available to meet initial project costs of any magnitude. The financial adviser on the project obviously should be consulted as to the desirability and comparative costs of any one of these mechanisms and be requested to examine options not suggested here.

Initial project costs of some magnitude are feasibility study costs, licensing costs, especially where a person intervenes before FERC to contest issuance of the license, and the costs of advanced design and engineering. For a site of $1.2 \mathrm{MW}$ 's (see Table I, Chapter III, Section G, supra.) feasibility study and licensing costs will approximate $\$ 25,000$ for a relatively trouble-free, straightforward project. This figure assumes that the $A E$ firm hired to do the feasibility study will have obtained the requisite information, as part of its study, from which to prepare and file a satisfactory license application. Advanced engineering costs are approximated at $\$ 150,000$ (158 of construction costs of the project) for the same site. (Table I, supra.)

The feasibility study must be undertaken at the initial stages of project study. At this point, the political subdivision, based on its reconnaissance study, has preliminary information indicating that further study of the project is warranted. The political subdivision may also have a preliminary permit. However, at this stage, there has been no independent engineering judgment made that the project is feasible. The financial community, at this stage, is unlikely to lend funds to the political subdivision for the feasibility study unless there is some security for the debt. Until recently, DOE, under its feasibility study and licensing loan program, would make low-interest, forgiveable loans to SSH developers, including political subdivisions, to finance up to 908 of the costs of feasibility studies and licensing of SSH projects. This program, however, is scheduled for termination. (Chapter IV, Section D, 2., infra.)

In the absence of the DOE loan program, political subdivisions will have to raise the funds for feasibility studies and licensing from other sources. One option is for the political subdivision to appropriate the funds out of current revenues. Given that 
the costs for a feasibility study will be in the order of $\$ 20,000-\$ 25,000$ for smaller projects and that proposals to perform the feasibility study can be solicited through a competitive RFP process, this method of covering the costs of the feasibility study appears attractive.

A second option is to issue G.O. debt, privately placed with a local bank, to secure the funds. An attractive feature of this option is that the debt incurred can be "rolled over" (the local bank can be paid off when and if the project's long term bonds are issued) upon long term financing. The disadvantages to such an option are the sometimes cumbersome process involved in issuing G.O. debt and the fact that the attendant costs of merely negotiating such a debt may be substantial when compared with the amount borrowed. In addition, not all states will permit their political subdivisions to issue bonds for such purposes. Even in states that do, the political subdivision may have to obtain ultimate approval for the project before any sums can be obtained. At such an early state in the analysis of the project, there may not be sufficient information to achieve this approval.

A third option, which may be limited to only a few political subdivisions, is for the political subdivision to borrow from a local bank and pledge, as security for the loan, the SSH site. The bank most certainly will require the political subdivision to hold a preliminary permit on the site. The holding of a permit, however, would not seem to be a problem in that an application for one could be prepared from the data obtained in the reconnaissance study and probably should be prepared anyway to preserve the subdivision's right to the site. The advantages of this type of loan are that such a transaction may be simply accomplished as compared to the issuance of G.O. debt. The disadvantages are that many, if not most, political subdivisions will encounter serious legal constraints in pledging public property as security for debt and, in fact, the laws of the state may view such transactions as merely another way of issuing G.o. debt.

A fourth option, again limited to a very few number of states, may permit the political subdivision to borrow from a revolving loan fund established by state law for the purposes of assisting political subdivisions and others in financing renewable energy or other types of energy related projects. Given the termination of the DOE loan program and the continuing strong interest of state legislatures in the development of a state's indigenous energy resources, state law should be consulted on a periodic and frequent basis to determine if such legislation has been recently enacted.

It should be noted here that the political subdivision, under any of the options outlined above, is "at risk" for the funds raised to pay for the feasibility study. In other words, if the project, upon study, proves infeasible the political subdivision stands to lose the funds appropriated out of current revenues or must somehow pay off the debt. Again, the financial adviser to the project should be consulted to assure that the most cost effective option is pursued and that any debt arrangement is negotiated on the most favorable terms available. (E.g., if the local bank lends the funds, the debt may be paid off over a long period of time if the project proves infeasible).

As an alternative to obtaining feasibility funding at its own risk, a political subdivision may be able to obtain some or all of the funds for feasibility analysis from outside sources. Thus, if the project appears relatively attractive from the reconnaissance study and the political subdivision appears comitted to self development, an $A E$ or engineering consultant firm may be persuaded to conduct the feasibility study on a contingency basis. This approach may even be available to provide important information for valuable sites which the political subdivision proposes to dispose of by bid or lease. Of course, it may be expected that contingent fee studies will be more expensive than normally funded studies. In addition, if all other funding sources are unavailable and the political subdivision still desires to be the principal developer, it may be expedient to release a portion of the proposed development to a private developer in return for the financing of the necessary study.

A second pre-construction and operation cost of significant magnitude is the cost of advanced design and engineering. This cost, as noted, could be as high as 158 of total construction costs. At the time these costs are confronted, the project has proceeded to an advanced state of planning. By this time, the political subdivision has in hand a detailed feasibility study which indicates the project is feasible and that a license or an exemption can be obtained. By this time also, the political subdivision 
either should have obtained a preliminary permit or should have filed an acceptable exemption application, if the site meets the conduit hydro or 5 MW exemption criteria, or an acceptable license application with FERC. The political subdivision should also have received enough information to determine whether it will encounter difficulty in obtaining an exemption or a license from FERC.

The advanced design and engineering study is necessary as a final evaluation of the project to ascertain whether there are any major, unforeseen problems not disclosed in the feasibility study, to develop final project drawings and to establish final, well substantiated estimates of project costs and timetables for purposes of developing and solicting bids for construction of the project. The latter is essential to determining the amount of any bonds issued to finance the project.

Several options are available to finance advanced design and engineering costs. To reiterate, the financial adviser to the project should be consulted concerning the availability and costs of alternative financing mechanisms.

There are a few, not many, $A E$ and engineering-consultant firms who are willing to underwrite the costs of an advanced design and engineering study for a contingent fee. In this instance, if the advanced design and engineering study and drawing confirm that the project is feasible and can be constructed within targeted construction costs, the consulting firm agrees to be paid from the proceeds of the bond issue or out of project revenues when the project comes on line. If the project is cancelled or encounters difficulties which cause it to be cancelled the consulting firm, under this contingent fee arrangement, gets paid nothing. It should be noted, that since the consulting firm takes the risks associated with underwriting initailly the cost of the advanced design and engineering study, its fee will be higher than if it were paid at the time the study was performed on a non-contingent basis. Recently, in regard to SSH development, consulting and $A E$ firms which are subsidiaries of substantial financial institutions, contractors or equipment manufacturers are offering a full range of engineering and financial services to 'SSH developers and, for a fee, are offering to provide funds to meet initial project costs. Under arrangements with these AE subsidiaries, the fees would take into account the risks incurred by the $\mathrm{AE}$ or consulting subsidiary and hence would be higher than fees paid if the $A E$ were not at risk. The fees under these arrangements are paid out of the proceeds of any bond issue or project revenues. In the case of these subsidiaries part of the fee may be an agreement to permit the parent company to be the banker on the bond issue, the contractor on the project or the supplier of equipment. The financial adviser should be requested to seek out such entities and compare their costs and range of services with the fees of other more conventional $\mathrm{AE}$ firms and the costs of financing the conventional, hence lower, $A E$ firm fees. Any offer by the subsidiary consultant or AE firm which includes the parent company providing banking services, acting as the general contractor or supplying equipment, should also be checked by the subdivisions solicitor and bond counsel to assure that the subdivision is not violating any competitive bidding requirements of state law. However, to the extent state law permits, the costs of the services and/or equipment offered as the "package" of services to be provided should be compared with other more conventional development strategies and considered carefully.

Another option to obtain funds for advanced design and engineering is to negotiate with the purchasing utility to have the purchasing utility commit to advancing the funds. In this instance, the purchasing utility has all but formally or, in fact has, agreed to a long term power purchase contract with the subdivision for all of the output of the project. There are a variety of ways such an arrangement can be structured. It can be part of the formally executed purchase power contract which will result in a lower price to be paid to the political subdivision for the power produced by the ssH project. It can be by an agreement separate from the purchase power contract pursuant to which agreement the utility advances the funds and is repaid from the proceeds of the bond issue. In this situation the utility will either be paid interest during the period that its loan to the political subdivision is outstanding or the price at which the power is sold to the utility will be reduced to reflect the interest on the loan. Under either arrangement it could be stipulated that the loan would not be repaid if the project could not be completed. The ability of the political subdivision to neogtiate such an arrangement with the purchasing utility obviously depends on the business acumen of the persons negotiating on behalf of the subdivision and the competition and need for power among potential utility purchasers. 
A third option would be to issue G.O. debt and place the loan with a local bank. Under this arrangement the restrictions on G.O. debt would have to be observed and the local banks would be repaid interest and principal from the subsequent bond issue. of course, if the advanced design and engineering study demonstrated that the project was infeasible, then the political subdivision would have to repay the loan and interest from tax and other general revenues.

A variation of this arrangement would also seem possible. Under this variation the political subdivision would have to have in hand a FERC license or an exemption. In addition, the political subdivision would issue G.O. or revenue bonds in an amount equal to estimated project costs (estimates based on the feasibility study) plus an amount to cover advanced design and engineering, plus an amount designated a "debt service reserve fund", plus an amount to cover underwriting and finance costs of the bond issue. Upon issuance of the bonds to cover these amounts the AE firm, underwriters and financial advisers would be paid their fees for their respective services. The "debt service reserve fund" would be used to pay debt service on the bond issue until the project generated sufficient revenues to pay debt service costs on its own. In addition, the political subdivision, immediately upon issuance of the bonds, would invest the proceeds of the bonds, after payment of the fees to the $A / E$ firm, underwriters and financial advisers, in relatively risk free higher yielding securities (e.g., treasury bills or other federal government securities). These securities in all probability would offer interest rates higher than the interest on the project bonds because ordinarily the interest is taxable on these federal securities under federal income tax laws. However, because the political subdivision is a tax exempt entity it will not pay taxes on interest payments (income) to it. The difference between the interest the political subdivision must pay on its bonds and the interest it earns on the higher yielding securities (in financial parlance, "the spread") may be used to defray the initial project costs and debt service requirements. Several caveats are in order concerning this variation in financing initial project costs.

To avoid the losing the tax exempt status of the bonds issued under such circumstances, care must be taken to satisfy the provisions of IRC Section lo3(c) relating to arbitrage bonds. In general, bonds issued by a political subdivision will be considered arbitrage bonds, and hence subject to federal income taxation, if a major portion of the proceeds are reasonably expected to be used to acquire securities which will produce a yield materially higher than the yield on the subdivision's bonds.17 The regulations under this section define "major portion of the proceeds" as an amount exceeding $15 \%$ of the issue and "material higher yield" as $1 / 8 \%$ for regular issues subject to the temporary holding period election and $1 / 28$ for other issues.18 Under code section $103(\mathrm{c})(4)$, the yield on amounts of an issue which are invested in a reasonably required reserve fund (generally not more than 158 of the issue) or issued for a temporary period pending their use for the purpose of the issue, will not trigyer arbitrage bond designation. For the purposes of funding upfront project costs from the yield on project bond issue, it is the conditions of this latter provision which will have to be carefully followed to avoid arbitrage bond designation.

To qualify for the temporary period exemption $85 \%$ of "spendable proceeds" must be expended on the project within three years from the date of issue and 958 must be expended within four years.19 spendable proceeds include the original proceeds minus the reasonable reserve requirement and debt service payments during the period.20 The political subdivision may elect, at the same time of issue, to use a 5 year expenditure period if the circumstances and facts at that time so warrant.2l An additional important requirement under this exemption is that the governmental unit enter a binding agreement to initiate the project financed by the issue within six months from the date of issue, or one year if justified by good business reasons. 22

Given the above restrictions, the timing of the issuance of the bonds relative to the projects completion (coming on line) is critical. The developer must have completed the feasibility study and have a license or exemption in hand to insure that it can proceed rapiaiy with the project once the bonds are 1ssued. Since there is the possibility that the project will be cancelled, the bonds must contain a provision that they may be "called" (repurchased from the bondholders at their face value and cancelled) by the political subdivision. One of the dangers of this strategy is that the difference between the interest rate on the federal securities in which the political subdivision invests the bond proceeds and the effective interest rate of the bond issue (the spread) may not be as great as anticipated. This would mean that the 
arbitrage strategy might not yield sufficient funds to defray all of the critical costs.

In any event, the complexities of this arrangement warrant advice and guidance by qualified financial advisers. It is an option, but one which requires skill and care to undertake.

Another possible option to finance initial project costs of advanced design and engineering is through a state created loan fund. As noted in connection with the discussion of feasibility study costs, states are examining the possiblities of creating such funds through legislation. To reiterate, newly enacted state legislation should be periodically reviewed to determine such loan funds have been acted.

\section{Bond Financing}

\section{Introduction}

Municipal (public entity) capital improvements can be financed by two basic types of bonds, the general obligation bond and the revenue bond. General obligation bonds are backed by the community's full faith and credit and are usually payable from general tax and other revenues. Revenue or income bonds are self-liquidating bonds whose interest and amortization payments are made from revenues generated from the improvement. Usually state law limits the borrowing that can be undertaken by general obligation bonds, while the amount that can be borrowed using revenue bonds is limited only by the investment characteristics of the project and current bond inarket conditions: In general, the interest on either type of bond issued by a political subdivision will be exempt from federal income taxes unless the use of or the security for the bond proceeds causes the bonds to lose their tax exempt status. This status can be restored by meeting certain Internal Revenue Code requirements. The conditions necessary to insure the tax exempt status of these bonds are discussed below.

The political subdivision can participate with the private developer in financing a small scale hydroelectric (SSH) project by issuing revenue bonds or industrial development bonds through an industrial development authority (IDA) or its equivalent. IDAs have been set up in 45 states to promote economic development and industrialization. They are public corporations vested with the power to acquire property and enter into contracts to borrow funds to assist ventures that qualify for their support. However, these bonds will only be tax-exempt if the requirements of Section 103 (b) of the Internal Revenue code (IRC) are respected. The requirements which bonds must meet in order that their interest payments are tax-exempt will be discussed later.

\section{General Strategy}

The first step in floating any bond issue is to estimate the funds required.. An estimate can be obtained by taking the engineering estimate of the total project cost and deducting the funds available from other sources. If the amount of funds required is small the developer may be able to place the bonds locally, perhaps at a bank or other financial institution.

If the amount of funds required is larger than can be raised from local sources, then the political subdivision should select an investment banker with hydroelectric development experience or its equivalent. financing:

Investment bankers typically perform two major functions with regard to bond

1. structuring the financing (determining the maturity and amortization for the bonds); and

2. marketing the bonds.

A good investment banker can serve as the financing center for the project and can provide some or all of the following services:

1. Preliminary Counseling; 


\author{
2. Financial Planning; \\ 3. License Preparation; \\ 4. Equity Syndication (for joint projects with private \\ developers); \\ 5. Preparing for Debt Financing; \\ 6. Underwriting and Marketing the Debt; and \\ 7. Detailed Investment Analysis.
}

Hydroelectric developers usually have a significant degree of flexibility in designing a financing plan and debt strucutre that is compatible with the economic characteristics of their projects. Developers with a knowledge of the project's general financing needs, the required permits and licenses, the regulatory and environmental considerations, the cash flow projections of the project and the general engineering for the project, will be able to deal most effectively with investment bankers. The bankers can then assess the characteristics of the project and the developer's objectives and devise a strategy for proceeding with the project.

In selecting an investment banker, the developer should consult two or three firms before making a decision. Usually, the firms' experience with hydro development and the range of services offered will vary widely. In addition, the investment bankers may only be interested in developers with experience in SSH, a sizeable project (\$l million and up), and a FERC license.

\title{
3. Debt strucuture
}

One factor which can be crucial in determining a project's financial feasibility is the debt amortization schedule. In most cases the developer can structure the financing of the project to produce accelerated, level, or deferred debt service payments. The general economic objective in financing capital intensive projects with debt is to obtain financing for a period of time roughly equivalent to the expected useful life of the facilities. If this is not possible, the objective should be to parallel the financing with the economic reality of the project. If total costs in the early years of the project nearly equal revenues, amortization should be deferred to reduce annual capital costs. The optimum debt service schedule will be that schedule whose present value of debt service payments discounted at the cost of the bond financing is lowest. It should be noted that recent developments (uncertainty) in the long term bond markets have substantially reduced the maximum term available for ssH and other bonds.

\section{Tax-Exempt Financing}

\section{a. General Considerations}

The lowest cost bond financing available is tax exempt bond financing. The Internal Revenue code specifically permits certain types of publicly. owned projects to be financed with debt obligations whose interest income is exempt from federal income taxes and often from state and local taxes. Since security buyers will pay a premimum to purchase these tax-exempt securities, interest rates on these securities are substantially lower than on securities that are not tax-exempt. For this reason publicly owned projects would tend to have a cost advantage over privately owned projects. However, there are certain stituations, described below, where the private developer can take advantage of tax-exempt financing if it is profitable for him to do so. In some cases the private developer may not find tax-exempt financing advantageous due to the loss of other tax credits, such as the 118 energy tax credit from the Windfall Profit Tax Act and, in some cases, the regular 108 investment credit.

Under the general rule of the Internal Revenue code interest on debt obligations issued by a state or political subdivision is exempt from federal income taxation. Furthermore, the interest may be exempt from state and local income taxation. Most electric utility śystems acquired or owned by a state, 
municipality, or state agency would qualify under this section of the IRC. Thus, SSH projects developed by these systems would be able to take advantage of tax exempt bond financing.

However, the general rule of Section $103(\mathrm{a})$ of the IRC that debt obligations issued by a state or political subdivision are tax exempt does not apply to those securities that the IRC classifies as industrial development bonds (IDB). Thus, the municipality that wishes to use tax exempt financing must avoid having the securities used to finance the SSH project classified as taxable IDB's under Section $103(b)$ of the IRC.

\section{Federal Income Tax Requirements: Section $103(b)$ of the Internal Revenue Code}

There are three tests that the Internal Revenue Code and the Treasury Regulations have enumerated for the purpose of assessing whether a governmental obligation is an IDB. These are known as the "trade or business test", the "security interest test", and the "output test".

If an obligation satisfies both the trade or business test and the security interest test, it will classified an IDB. The output test is an alternative criterion applied by the IRS to certain energy output facilities, owned and operated by exempt persons, in lieu of both the security test and the trade or business test. Therefore, a municipality intent on avoiding classification as an IDB must fail to satisfy the trade or business test and the security test or, if applicable, the output test.

\section{a. Trade or Business Test}

The first step in avoiding classification as an IDB is to avoid meeting the trade or business test. This test is satisfied if "all or a major part of the proceeds of a bond issue are used directly or indirectly in any trade or business carried on by a person who is not an exempt person.23 This section of the Internal Revenue Code is more easily understood when it is realized that its purpose is to prevent a governmental unit from enticing private industry into its district by subsidizing that industry with tax-exempt bonds.

This test is quite basic. A political subdivision can in no way funnel revenue to private entities for use in their trade or business if that revenue constitutes a major portion of a tax-exempt bond issue. "Major portion" has been defined as more than twenty-five percent of a bond issue" 24

The regulations to the IRC are quite specific in delineating the various transactions that a political subdivision can enter into with a private entity that will satisfy the trade or business test. For example, if the proceeds of a bond issue are to be used to construct facilities to be leased or sold to any non-exempt person for use in its trade or business, this satisfies the trade or business test.

The regulations state that "proceeds will be treated as being used in a trade or business of a non-exempt person in situations involving other arrangements, whether in a single transaction or in a series of transactions, whereby a non-exempt person uses property acquired with the proceeds of a bond issue in its trade or business." 25

It is apparent that section $103(b)$ forces subdivisions to use the major portion of a tax-exempt bond issue in conducting their own trade or business or in the trade or business of exempt entities like themselves.

However, this does not mean a political subdivision cannot invest in facilities for which it does not assume full responsibility. A municipality may opt to use bond proceeds to construct or retrofit a facility in conjunction with a private developer. In that situation, the bond will enjoy tax-exempt status as long as the subdivision assumes the risks and responsibilities of ownership proportional to its investment in the facility.26 In practical terms, if a political subdivision puts up 508 of the cost of a facility using tax-exempt bonds, it must assume the risk and responsibilities for 508 of the ownership and 
operating expenses. The Internal Revenue Service will apply the trade or business test only to the portion of the facility that the subdivision has financed with the tax-exempt bonds. It will in effect ignore the portion of the facility to the extent of the investment made by a private entity. Therefore, if 508 of a $200 \mathrm{MW}$ facility is financed by a political subdivision, the IDB tests will only be applied to $100 \mathrm{MW}$ of the facility (the 508 that the governmental unit financed with tax-exempt bonds). This ensures that the subdivision will assume the risk of ownership corresponding to the amount of its tax-exempt investment.

\section{b. Security Interest Test}

Since an IDB is defined as trade or business carried on by a private entity and secured by an interest in property to be used in a trade or business of a private entity, a municipality can also avoid having its bonds classified as IDBs by not meeting the security interest test. As set out by the IRC, the test is whether all or a major portion (25\%) of the payment of the principal or interest on the bond issue is secured by or derived from property used in the trade or business of a non tax-exempt persun.27 A political subdivision may be able to avoid meeting the security interest test by using general obligation bonds. General obligation bonds are those that are backed by the full faith and credit of the governmental entity issuing the bonds. To avoid meeting the security interest, the subdivision secures the bonds solely with the full faith and credit of the state. This avoids satisfying the security interest test because the bonds are not secured by interest in property to be used in the trade or business of a private entity.

However, a pledge of the full faith and credit of a governmental entity will not automatically prevent a debt obligation from meeting the security interest test. If the bond is secured by both a pledge of full faith and credit and "any interest in property used or to be used in a trade or business" of a private business user, the bond issue satisfies the security interest test and cannot thereby achieve tax-exempt status. Therefore, the political subdivision must issue general obligation bonds that are not additionally secured by an interest in property used in a non tax-exempt entity's trade or business. The nature and source of the security for the bonds may be "..determined from the terms of the bond indenture or on the basis of an underlying arrangement." An underlying arrangement to provide security for, or the source of, payment of the principal or interest on an obligation may result from separate agreements between the parties or may be determined. on the basis of all the facts and circumstances surrounding the issuance of the bonds."28 Therefore, it is apparent that a bond issue that includes a general obligation backing will be scrutinized to ensure that the arrangement is not structured in such a manner that meets the security interest test. The major advantage that accrues to a political subdivision that issues general obligation bonds that are tax-exempt is once again greatly decreased financing costs. Also since the bonds would be tax-exempt by virture of failing to meet the security interest test, the trade or business test need not be reached.

Although there are obvious advantages to guaranteeing a bond issue with the full faith and credit of the political subdivision, there are disadvantages. As noted earlier, because of fiscal and legal constraints, the subdivision may not have enough revenues to cover the cost of a power project should it fail as a profitable enterprise. However, should the fiscal and legal constraints prove minimal, the financial risks involved in using the full faith and credit of a municipality or state for the financing of capital intensive hydroelectric projects become obvious. As a result, the decision must be made regarding whether the financing advantages outweigh the disadvantages of a general obligation issue.

\section{c. Output Test}

If a political subdivision floats a revenue bond to finance the rehabilitation of a small scale hydroelectric facility that it owns and will operate, and the subdivision will use all of the facility's power for its own energy needs, there is no question that the bond issue is tax exempt. However, in the circumstances covered by this manual, it is assumed that the political subdivision will be selling the bulk of the power to a utility which is not tax 
exempt.

In situations such as these, the Treasury regulations set out an alternative test (to the trade or business test and the security test) for the purpose of determining IDB status. This alternative, the "output test", is only available to certain output facilities "such as electric energy, gas or water facilities" which are "owned and operated by an exempt person".29 For these facilities, the Service merges the trade or business and security interest tests into a single test whose primary focus is the tax status of the power recipient and the terms of a legal obligation governing the supply of that power. The Treasury is concerned with the situation where the benefits of a facility ownership and the burdens of paying the debt service on government obligations used to finance the facility are effectively transferred to a non-exempt person.

Under IRS regulations, the benefits and burdens are considered to be so transferred where a municipality sells more thant 258 of the power produced by the facility over the life of the bonds to a non-exempt person under a "take, or take or pay" contract. The operative percentage is derived by dividing the amount of power committed under contract (output per year multiplied by years of contract) by the amount of power financed (capacity of the plant multiplied by term of bond issue). 30

There are three key tests contained in this regulation. The first relates to "non-exempt persons". A political subdivision is not restricted from selling its output to exempt entities; i.e.r. for purposes of the $758 / 258$ output test, sales to these entities are not included in the 258. The definition of "exempt person" is quite restricted, however. For the purposes of section 103(b), an exempt person is either a government unit or an organization exempt from taxation under code Section $501(c)(3) .31$

Governmental units include state or local governmental units, including a State, Territory, possession of the United States, the District of Columbia, or any political subdivision thereof. 32 The term "political subdivision" denotes "any division of any state or local government unit which is a municipal corporation or which has been delegated the right to exercise part of the sovereign power of the unit". "Section 501(c)(3) organizations" are essentially those operated exclusively for religious, charitable, scientific or related purposes. It would seem then, that an exempt person would not include rural electric cooperatives and other tax-exempt non-governmental entities.

The next important test concerns the circumstances under which the power is sold to a non-exempt person. The regulations state that an arrangement where a non-exempt entity agrees "to take, or take or pay" for more than 258 of the debt service life output from an otherwise exempt facility will cause the bonds for the facility to be considered IDBs. 33 The examples in regulations which are intended to demonstrate the application of this provision are limited to contracts under which the output from a project is sold to a non-exempt entity on a "take or pay" basis (i.e., for code purposes here, a contract where the purchaser agrees to pay for a certain quantity of power at a certain price, whether or not it is delivered).34 Nevertheless, the scope of Regulation $1.103-7(b)(5)$ seems clearly to extend to any long term contractual agreement where the exempt entity agrees to purchase a certain quantity of power at a certain price (or formula). Thus, it would seem that non-exempt entity purchases under any agreements to purchase a certain amount of power would be subject to the 258 limit. However, it may be perfectly permissible for a subdivision to sell as much of its ouput as it desires on a short-term, non-committal basis. The conceptual key to the distinction between the two types of agreements is whether the non-exempt entity has had the benefits of ownership and the burden of paying the debt service transferred to it. As a result, a unilateral decision by a political subdivision to sell its facility's output to various utilities under prevailing rates may not be considered a transfer of burdens and benefits, but it seems certain that no contracts could be executed obligating non-exempt persons to purchase any specified amount of power for any specified period of time without being considered such a transfer.

The third key test is the one that requires that the $258 / 758$ test will be 
applied to the facility's output to non-exempt entities "over the term of the bonds". 35 This wording permits a municipality to sell to such entities more than 258 of the facility output during the first few years of the debt (which will decrease upfront financing costs) as long as it correspondingly. sells less than 258 of the output in the later stages of the bond term. For instance, if a political subdivision constructs a 10 megawatt (MW) facility with bonds issued for a 20 year period, it clearly satisfies the "758/258" rule if it has a take/take-or-pay contract for the sale of 2 MW per year to the local investor-owned utility in each of the 20 years of the bond term (and therefore retains tax-exempt status). This amounts to $40 \mathrm{MW}$ sold during the 20 years which is less than 258 of the available 200 MW produced during that time. However, it may be of greater financial benefit to the subdivision for it to sell 4 MW per year for the first 10 years on a take-or-pay contract. Although the 4 Mw represents 408 of the facility's output during those 10 years, and would appear to violate the "75\%/258" rule, the duration of the contract is only 10 years. As long as the political subdivision does not enter into any more take-or-pay contracts for the final 10 years of the term of the bonds, the total number of MW sold under the contract remains 40 , which is less than 258 of the facility's output over the term of the bonds. Not only will this mechanism be financially advantageous, it will allow a municipality to have access to more of its facility's power 10 years in the future when its energy demands may have increased.

The regulations under section $103(b)$ also state that those taxable purchasers who purchase 38 or less of the municpality's capacity are not included when the percentage of capacity sold to taxable purchasers is calculated. 36 This special provision would allow a favorably situated political subdivision to sell more than 258 of its capacity to taxable purchasers. In addition, sales to exempt utilities such as municipal utilities are not included in the 258 limit. Thus, the political subdivision that is fortunate enough to take advantage of these definitions of IDBs in the code could fully develop a site that was considerably larger than its present needs and still take advantage of tax-exempt financing.

\section{d. Specific Exemptions to the IDB Classification}

Even if a bond issue meets both the security interest test and the trade or business test (or the output test) a municipality can still issue the exempt bonds if it can qualify for any of the exemptions to the IDB classification. There are three exemptions that are of particular interest to SSH developers. These are the exemptions for small issues, local furnishing of electricity, and the qualified generating facilities exemption under the Crude Oil Windfall Profit Tax Act (COWPTA). It should be noted here that the tax-exempt status of the bonds will be lost for the period of time that the bonds are held by a substantial user of the hydro facility or a related person under any of the above exemptions.

\section{i. Small Issue Exemptions}

The small issue exemption is a general term that actually embraces two types of exemptions: (1) an exemption for bond issues not exceeding $\$ 1,000,000$; and, (2) the special election that exempts bond issues not exceeding $\$ 10,000,000$. In both instances, the bond proceeds may be used for the development of a privately owned hydroelectric generating facility. The Code does somewhat limit the use of the proceeds from a $\$ 1,000,000$ limit and, to an even greater extent, those from a $\$ 10,000,000$ special election issue. 37 The issuing entity may opt for either form of the exemption. Since the guidelines for the $\$ 10 \mathrm{million}$ are built upon those for the $\$ 1$ million, the latter will be described first.

\section{(a) The \$l Million Small Issue}

The \$l million small issue exemption applies to Industrial Development Bonds which are part of an issue with an aggregate authorized value of $\$ 1,000,000$ or less. Substantially all of the proceeds of the bonds must be used in either of two ways: (1) for the acquisition, construction, reconstruction, or improvement of depreciable property or land; or, (2) to redeem all or part of a previously issued exempt small issue. 
The phrase "substantially all" has been determined to require that 908 of the proceeds must be used for one of the two permitted general purposes. Hence no more than 108 of the proceeds may be used for working capital. This requirement should not be much of a problem for hydroelectric development, since most of the expenditures associated with the construction of a new dam or the retrofitting of an old one involve acquisition, construction, reconstruction, or improvement of property subject to a depreciation allowance. The only major expenses falling outside of this condition would be the cosț of any engineering or feasibility studies.

The proceeds of a $\$ 1$ million exempt small issue may be combined with other financing arrangements to fund a larger project. The additional capital need not be raised by tax-exempt financing, so long as the security for the separate bond issues is distinguishable. Such a combination of financing is possible under the $\$ 10 \mathrm{million}$ aggregate limit.

A developer whose project was financed by the proceeds from a small issue may use the proceeds of a second bond issuance, up to the $\$ 1$ million limit, to redeem that part of the first issue which remains outstanding, and use the remaining proceeds for any allowable expenditures. For example, if $\$ 100,000$ of an issue has been repaid, leaving $\$ 600,000$ outstanding, a developer might use the proceeds of a new $\$ 1$ million issuance to retire the remaining $\$ 600,000$ debt, and expend the left-over $\$ 400,000$ for additional equipment to increase the capacity of the project. The rule here is that the total outstanding indebtedness is permitted to always be $\$ 1$ million. 38

It is important to note that for the purposes of calculating the $\$ 1$ million limit, the IRS will aggregate the outstanding indebtedness of all prior small issues to be utilized by one principal user (or related person) for facilities located within the same municipality or unincorporated portion of one county, including those issued by a different governmental corporation.

Further, oustanding bonds issued after August 7, 1972 with respect to contiguous or integrated facilities, located on both sides of a border between two jurisdictions, will be treated as prior issues made in both jurisdictions: Such a situation could arise in a hydroelectric development located on a river which is also a political boundary.

\section{(b) The $\$ 10$ Million Small Issue}

The Revenue Act of 1978 allows the issuance of exempt bonds w1th a face value of up to $\$ 10$ million. The rules for these small issues are the same as those for the $\$ 1$ million small issues, with two additional requirements.

First, the issuing governmental body must "elect to have the $\$ 10$ million limit apply. 39 This requirement is fulfilled simply by filing a certificate with the IRS. Such an election applies only to the individual issue under consideration, and has no bearing on any prior or subsequent bonds.

Second, certain capital expenditures must be deducted from the $\$ 10,000,000$ limit in computing the permissible amount of the issue subject to this exemption. Capital expenditures paid or incurred during a six year period running from three years before the date of issue to three years after such issue must be included. If the total of project costs and includible capital expenditures exceeds $\$ 10$ million, only $\$ 1$ million of the bonds will be exempt. Prior issues as well as prior and subsequent capital expenditures will be aggregated in this computation. 40 It is crucial that the political subdivision and the private developer consider this limitation when making business decisions, for some seemingly unrelated business expenditures may be included, thus jeopardizing the tax-exempt status of the project financing.

The capital expenditures made within the six year period which are 
taken into account are defined as those: 41

1. Properly chargeable to a capital account, despite any code provisions which might permit expensing such capital item;

2. Made with respect to any facility located within the same political subdivison and principally used by the enterprise for whom the issue was floated, or a related person; and

3. Not financed out of proceeds of prior outstanding issues (this prevents aggregating the same expenditure twice).

The following hypothetical example illustrates the second test above. Municipality $A$ elects to issue an $\$ 800,000$ bond to finance the retrofitting of an old dam, formerly used and now again to be used, to provide power for manufacturer $B$. Two years after the issue, $C$ constructs, at the cost of $\$ 250,000$, a warehouse at another site within municipality $A$. $B$ and $C$ are both owned by holding company $D$. C's expenditure. is includable since it was made with respect to a facility within the same political subdivision by a person related to the enterprise for whom the issue in question was made.

Capital expenditures not. taken into account for the $\$ 10$ million exemption are those:

1. Necessary to replace property destroyed or damaged by casualty (up to market value);

2. Required by changes in federal or state law;

3. Neçessitated by unforeseen circumstances (up to $\$ 10,000,000$ ) 42 or

4. Made by a public utility which is not the principal user of the facility.

A final exception to the capital expenditure computation concerns projects funded under Urban Development Action Grants (UDAGs). 43 For such projects the Code permits up to $\$ 10 \mathrm{million}$ in capital expenditures to be excluded from the $\$ 10$ million exempt small issue calculation. In essence this allows up to $\$ 20 \mathrm{milli}$ ion of financing for a hydroelectric project which is linked with a UDAG, provided that no more than $\$ 10$ million is in the form of exempt. small issue bonds.

It appears that most publicly and privately (or jointly) developed SSH projects likely to obtain. financing assistance from a state or local IDA would be able to satisfy the general requirements of the $\$ 1$ million and $\$ 10$ million small issue exemptions. In using these exemptions, it should be borne in mind that the usefulness of the $\$ 10$ million exemption is 1 imited by the requirement that capital expenditures made by the private participant in the project within the political subdivision must be counted toward the $\$ 10$ million limitation.

\section{ii. Local Furnishing Exemptions}

The local furnishing of electric energy exemption may provide another method for a jointly developed hydroelectric project to obtain tax-exempt industrial development bond financing. 44 Its primary advantage over the small issue exemption is the absence of the amount of issuance and capital expenditure limitations. However, the terms of the exemption are exacting and compliance depends to $a$. degree on. factors outside the developers' control.

Substantially all the proceeds of such a bond issue must be used to provide the exempt facility. This substantial use requirement is met if 908 of the proceeds used are expenditures (paid or incurred) chargeable to the facility's capital account. Treasury regulations define exempt facility to include any land, building, or other property which is functionally related 
and subordinate to the facility.45 Expenditures on land acquisition (for dam site as well as property needed for impoundment), generation equipment, and transmission lines should all be allowed by this provision.

Under this Code exemption, options for disposition of the facility's output are limited by a public use requirement.46 Meeting the following dual test will fulfill this requirement: (1) the owner or operator must be obligated by law, ordinance or regulation to furnish electric energy to all persons, within its service area, who desire electric service; and (2) it must be reasonably expected that such a facility will serve or be available to a large segment of the general public in the service area.47 This public use test may preclude the local furnishing of electricity exemption for projects which will supply electricity only to a single large "ultimate" user, such as an industry.

Ultimately, the definition of the local furnishing of electric energy will determine a SSH project's ability to utilize this exemption. Four criteria must be satisfied to enable such projects to qualify. Qualifying facilities are those which:

1. The property is either of a character subject to the allowance for depreciation provided in Section 167 of the Code, or land;

2. Produce, collect, generate, transmit, store, distribute, or convey electric energy;

3. Are in the trade or business of furnishing electric energy; and

4. Are part of a system providing service to the general populace of one or more communities or municipalities, but in no event more than two (2) contiguous counties (or political equivalent). Such counties need not be located in one state. 48

This two county limit may pose a hurdle which a hydroelectric project cannot easily overcome. Since most electric generation projects and their distribution systems are integrated into an electric supply grid, it is difficult to definitively establish that a particular electrical supply will not be distributed beyond two particular counties.

To be certain of limited distribution, the local system would have to be completely isolated from the grid. Points of interconnection may have switches maintained in an open (disconnected) position, thereby electrically isolating the local system. Interconnection is permitted for the emergency transfer of electricity, 49 and in emergency situations, the switches may be closed to permit temporary transfers of power. The IRS will apparently approve any such arrangement where there are assurances against any net outflow of power from the system over any extended period of time. 50

According to some bond counsel, where the local generating facility capacity is less than the lowest service area demand and flow to the grid is precluded by breakers, the local furnishing requirement will likely be satisfied. The remaining demand is constantly supplied from outside the two county limit, thus no outflow of power is anticipated. The breakers are installed to cut off the connector if a reversal in flow occurs. 51

A similar, but less restrictive, arrangement was recently approved in an IRS private letter ruling approving the tax exempt status of a power project installed without switches or breakers. The IRS ruled that the fact that the system demand in the local area substantially exceeded the facility's generating capacity at all times created such a low probability of outflow that the two county test was satisfied.52 Although all private letter rulings are decided on an individual basis, with no precedential value attributed to those decided previously, they do provide some insight into current IRS positions. The most recent ruling is particularly encouraging and may well indicate the IRS's willingness to approve a broader scope of circumstances in allowing tax-exempt status for bonds under the 
local furnishing exemption.

\section{iii. Qualified Hydroelectric Generating Facilities Exemption}

The Crude oil Windfall profit Tax Act (COWPTA) created a third potential exemption for hydroelectric developinent. Under this exemption the interest on municipal bonds used to finance qualified hydroelectric generating facilities is exempted from federal income taxation. Public ownership of the dam site is a requirement for "qualification" under this exemption. Accordingly, the provision is likely to benefit exclusively public SSH projects and projects in which there is joint participation by the public owner and the private developer. Such private participation may consist of arrangements that provide for: 1) development/operations contracts with the municipality; or 2) joint ventures. These arrangements will be discussed in further detail following a brief summary of the salient provisions of this exemption.

The general requirements are the same as those applying to other exempt activities under the code. 53 That is, the exemption only applies to industrial development bonds in which a substantial (908) portion of the proceeds must be applied to the exempt activity and which satisfy the public use test. 54

A qualifying project consists of "qualified hydroelectric generating property" under Code Section 48(1)(13). This means an existing dam whose construction was completed before october 18, 1978. The dam must be owned for tax purposes by a government entity as of october 18, 1979 and continuously thereafter for the life of the tax exempt debt. No significant enlargement is permitted after this date. Sites not utilizing any dam or impoundment of water qualify without regard to date of ownership. Finally, the project must be one with generation capacity less than 125 MW. 55

The term "qualified facility" means any qualified hydroelectric generating property installed at a qualified site. Such qualified property is equipment for generating electric energy from water, structures for housing this equipment, fish passageways, and dam rehabilitation property required by reason of the installation of the electrical generation equipment at the qualified site.56 Transinission stage equipment is specifically excluded. 57 permitted dam rehabilitation includes renovations, reconstruction of breached structures, and, in some instances, complete replacements of entire impoundment structures. 58

The limitation on the amount of tax-exempt proceeds available under this financing method hinges on eligible costs and the size of the generating capacity of the project. Eligible costs are those reasonably expected to be the cost to the governmental body attributable to periods after October 18, 1979 and before January $1,1986.59$ Thus, if a municipality is a co-developer in joint venture with a private concern, on an equal share basis, one half of the amount for qualified hydroelectric generating property would be eligible costs.

Proceeds applicable towards the eligible costs are proportionate to the total generating capacity of the facility. 60 Qualified property of projects with capacities of 25 MW or less may be financed by exempt proceeds in total. This proportion decreases, to zero, as capacity increases to the maximum capacity of $125 \mathrm{MW}$.

The exact amount of the proceeds which may be used is determined by the product of the eligible cost and the "installed capacity fraction.61 By "installed capacity fraction" the code means the fraction of which:

1. The numerator is 25 , reduced by 1 for each megawatt by which the installed capacity exceeds $100 \mathrm{MW}$; and

2. The denominator is the number of megawatts of installed capacity (but not to exceed 100$) .62$ 
Some public entities may wish to develop qualified dam sites utilizing this tax exempt financing, but lack the in-house technical capability. An opportunity is presented here for a private developer to profit from a contractual relation, with the public entity, to develop and operate the hydroelectric facility. Compensation by the public entity to the private contractor may be based on a flat fee for specific work performed or on a percentage of the revenues generated.. However, each individual contract should be drafted so that the municipality clearly remains the owner of the facility. If the benefits and burdens of ownership appear to the service to have shifted from the municipality to the private developer, the tax exempt status of the IDBs will be in jeopardy due to violation of the continuous public ownership requirements. 63 Any long term lease arrangements between a municipality and a private developer will likely be construed as a violative shift in ownership.

It is clear that solely municipal projects up to $25 \mathrm{MW}$ enjoy the maximum benefit of this exemption. However, the option should also be attractive to private and public joint ventures for larger projects, illustrated by the following example. A municipality enters into a joint venture with a private concern to install an additional 40 MW of generating capacity to an existing dam owned by the municipality, at which $10 \mathrm{MW}$ of generating capacity presently exists. The entire project cost is $\$ 30$ million, of which $\$ 20$ million is qualified hydroelectric generating property and functionally related and subordinate equipment. An an equal joint venture, the municipality's share of the cost of the qualified hydroelectric generating facilities is $\$ 10$ million. The maximum amount of exempt bond proceeds that can be used for the qualified property is $\$ 5 \mathrm{million}(25 / 50 \mathrm{x}$ $\$ 10$. million).

In such a case, the tax ownership may be split between the public entity and the private party. This will allow the municipality to finance its portion using the qualified hydroelectric generating facilities' exempt IDBs and the private developer to utilize other financing methods and recoup some of his investment through the investinent tax credit and energy tax credit (See section III.B. of this manual).

It should be noted that interest on these bonds is not excludable when such bonds are held by a substantial user of the facility, or a related person. Further, these industrial development bonds must ve issued in registered form as to principal and interest for the entire life of the obligation, and payment of the principal or interest may not be guaranteed or paid, in whole or in part, directly or indirectly, with funds from any federal, state or local program whose principal purpose is to encourage the conservation of production of energy.64 While the requirement for registration appears to be the trend for all tax-exempt issues, it should be noted that a recent attempt to use the COWPTA exemption indicated that low market acceptance and increased interest rates may be expected for such bonds in the short term.

\section{Federal Financial Assistance}

\section{Introduction}

With the prospect of extensive cuts in the budgets of various federal agencies and even the abolition of entire agencies and programs with agencies, a SSH developer's prospects for obtaining financing assistance from the federal government may be remote. Given these conditions, this section will necessarily be brief. Since a developer may wish to make inquiries concerning the availability of federal financing assistance from any number of agencies, these agencies will be listed and their programs briefly described. It may be that a particular office of one of the agencies described below will be willing to enter into an arrangement with a developer. However, given the present economic conditions and the initiatives emanating from Washington, developers should not count on obtaining financing assistance from a federal agency or program.

\section{Department of Energy}


Until recently the Hydroelectric Resources Development. Division of DOE extended low-interest loans to assist developers of projects greater than $100 \mathrm{KW}$ and less than 30 MWs in capacity in undertaking feasibility studies and obtaining licenses. The loans were forgiveable if the project proved infeasible or through no fault on the part of the developer, the developer was unable to obtain a license. plans have been inade to abolish this program.

\section{Farmers Home Administration}

The Business and Industrial Loan Program of the Farmers Home Administration (FmHA) was designed to provide financing assistance in the form of guarantees of loans or insured loans to enterprises in rural communities. Insured loans under the program are only available if the applicant cannot obtain creuit elsewhere. Guarantees are available, notwithstanding the availability of credit elsewhere. This program at one time was designated to assist SSH developers, among others, in rural communities.65 However, no applications were or have been received by FmHA from SSH developers under this program.

\section{Small Business Administration}

The Small Business Administration (SBA) can provide assistance in the form of direct loans, participation loans and guaranteed loans to small businesses. This source of assistance, however, was never specifically designated to assist SSH developers in rural communities. Direct loans are available only if participation loans or guaranteed loans are unavailable. Participation loans are available if guaranteed loans are unavailable. The maximum guarantee under guaranteed loans is 908 of the principal of the loan. To obtain SBA assistance, a developer must qualify as a small business and provide satisfactory evidence that he does not otherwise have access to credit on reasonable terms.

State and local development company loans may also be available to developers, but their availability depends on the existence of a state or local development company within the state in which the developer seeks to develop the project. Under this program, a developer will make arrangements. with the local development company for a loan and the local development company, in turn, will deal with the SBA in undertaking the loan.

Under this program, the SBA may license a Small Business Investment Company (SBIC) to assist small businesses, including SSH developers. Under arrangements with a developer an SBIC will lend capital to a developer in exchange for an opportunity to participate, as an equity owner, in the growth of the small business (i.e., ssH project). Currently, there is at least one SBIC in the SSH development business.

\section{Other Programs and Agencies}

The Rural Electrification Administration (REA), the Economic Development Administration (EDA), and the Department of Housing and Urban Development (HUD) all have programs which theoretically could benefit ssH developers, but which are practically unavailable.

The REA's programs are, for all intents and purposes, limited to assisting rural electric cooperatives and municipal electric utilities which have borrowed or received guarantees or loans from REA in the past. Plans have been made to abolish EDA, and the program operated by HUD, the Urban Development Action Grant Program (UDAG), which could have indirectly assisted SSH developers, is also scheduled for abolition. 
$1_{16}$ U.S.C. $\$ 798(1976) ; 44$ Fed. Reg. 61,337 (1979).

${ }^{2}$ FPC v. Union Electric Co., 381 U.S. 90, reh. denied, 381 U.S. 956 (1965).

${ }^{3}$ Connecticut Light and Power Co.v. FPC, 557 F.2d 394 (1st Cir. 1977).

418 C.F.R. $\$ 131.6(1979)$.

544 Fed. Reg. 67,644 (1979).

645 Fed. Reg. 28,080 (1980) (conduit hydro); 45 Fed. Reg. 76,115 (1980) (5 MW exemption).

716 U.S.C. $\$ 800(a) .(1976)$.

844 Fed. Reg. 61,336 (1979) (to be codified in 18 C.F.R. $\$ 4.33(\mathrm{~g})$ ).

$9 \underline{\text { Id. }}$

$10_{\text {Id. }}$

1145 Fed. Reg. 76,115 (1980).

1216 U.S.C.A. $\$ 824(a-3)$ (Supp. 1980).

1345 Fed. Reg. 12,214 (1980). (To be codified in 18 C.F.R. $\$ 292.303$ et seq.)

14 In finance, a number of terms are used to denote different contractual relationships. For purposes of this manual the term "Hell or High Water" contract will be used to describe a contract whereby the purchaser guarantees payment of all debt service for the financing period of the project regardless of whether power is delivered. This type of contract is also frequently referred to as a "Take or pay" contract.

15 Notice of Inquiry, FERC Docket No. EL81-9-000 (Issued February 19, 1981 ).

16 If the flow of tax or other payments from an alternative development scenario is expected to be more certain than the project revenues from self-development, a somewhat lower discount rate should be used to reflect the lower risk.

1726 U.S.C. $\$ 103(\mathrm{c})$.

18 Treas. Reg. $\$ 1.103-13(b)(1)(c)$ and $1.103-13(b)(5)$.

${ }^{19}$ Treas. Reg. $\$ 1.103-14(b)(2)(i i)$.

20 Treas. Reg. $\$ 1.103-14(\mathrm{~b})(2)$ ( $i$ ii).

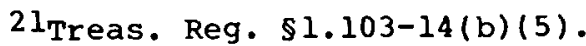

22 Treas. Reg. $\$ 1.103-14(b)(3)$.

23 Treas. Reg. $\$ 1.1 .03-7(b)(3)$.

24 Treas. Reg. $\$ 1.103-7(3)(\mathrm{iii})$.

25Treas. Reg. $\$ 1.103-7(b)(3)$.

26 Treas. Reg. $\$ 1.103-7$ (c) (Example 13).

2726 U.S.C. $\$ 103($ b) (2) (A); Treas. Reg. $\$ 1.103-7(b)(4)$.

28 Treas. Reg. $\$ 1.103-7(b)(4)$.

${ }^{29}$ Treas. Reg. $\$ 1.103-7(G)(5)$. See also Treas. Reg. $\$ 1.103-7(\mathrm{c})$ Example 13.

30 Treas. Reg. $\$ 1.103-7(b)(5)$. 
$3 l_{\text {Treas. Reg. } \$ 1.103-7(b)(2) .}$

32 Treas. Reg. $\$ 1.103-7(b)(2)$.

33 Treas. Reg. $\$ 1.103-7(b)(5)$.

34 Treas. Reg. $\$ 1.103-7(c)$. (Examples (13) and (15)).

35 Treas. Reg. \$1.103-7(b)(5)(ii).

36 Treas: Reg. $\$ 1.103(b)(5)(i)(a)$.

37 Treas. Reg. $\$ 1.103-10(b)$ (ii).

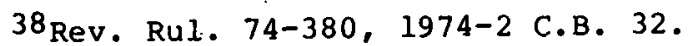

${ }^{39} 26$ U.S.C. $\$ 103(\mathrm{~b})(6)(D)$.

4026 U.S.C. $\$ 103($ b) (6)(D) (ii).

$41_{\text {Treas. Reg. } \$ 103(b)-10(b)(2) .}$

42 Such as strikes, inflation, architectural modification, erroneous cost estimates, weak soil support for foundations, or inçreased engineering fees.

43UDAGs are not directly available to private developers. Eligible municipalities, however, may serve as a conduit or grant money to private developers.

4426 U.S.C. $\$ 103(b)(4)(E)$.

45 Treas. Reg. $\$ 1.103-8(a)(3)$.

46 Treas. Reg. $\$ 1.103-8(a)(2)$.

47Treas. Reg. $\$ 1.103-8(E)(2)(\mathrm{i} i)$.

48 Treas. Reg. $\$ 1.103-8$ (f)(2) ( $i i)$.

49 Id.

$50 \mathrm{Pr}$. Rul. $7101260590 \mathrm{~A}$.

51 opinion provided to the city of Portland by bond counsel regarding the status of bonds to be issued to finance a city SSH project selling to the grid. No IRS ruling was sought.

52Pr. Rul. 8041074 .

5326 U.S.C. $\$ 103($ b) (4).

${ }^{54}$ Treas. Reg. $\$ 1.103-8(a)(1),(2)$ (1979). P.L. 96-223 4/2/80, Conf. Rep. p. 149 .

$55_{26}$ U.S.C. $\$ 48(1)(13)(B)$.

5626 U.S.C. $\$ 48(1)(13)($ A).

57P.L. 96-223 4/2/80, Conf. Rep. p. 149 .

58 Id. at p. $149-50$.

5926 II.S.R. $\delta 103($ b $(0)(E)$. This periód shall be extended until Jan. 1 , 1989 for projects with applications docketed by FERC before Jan. 1, 1986.

${ }^{60}$ During the three taxable years following the taxable year in which the equipment is initially placed in service. 26 U.S.C. $\$ 48(1)(13)(E)$. 
$61_{26}$ U.S.C. $\$ 103(b)(8)(c)$.

6226 U.S.C. $\$ 103(B)(8)(D)$.

6326 U.S.C. $\$ 103($ b) $(8)(\mathrm{i} i)$, Rev. Rule 68-590, 1968-2 C.B. 66 .

6426 U.S.C. $\$ 103(h)$.

65 In an interagency Memorandum of Understanding, the White House, in May of 197.9, established a program of assisting Small scale Hydroelectric development in rural areas. FmHA was a signatory to the Memorandum. The fate of this program is uncertain, at best, with the change in administrations and the announcement of President Reagan's new economic program. 
UNITED STATES

DEPARTMENT OF ENERGY

WASHINGTON, D.C. 20585

OFFICIAL BUSINESS

PENALTY FOR PRIVATE USE, $\$ 300$
POSTAGE AND FEES PAID

U.S. DEPARTMENT OF ENERGY DOE 350 